University of Nebraska - Lincoln

DigitalCommons@University of Nebraska - Lincoln

Publications, Agencies and Staff of the U.S.

Department of Commerce

U.S. Department of Commerce

2008

Integrating genetic data into management of marine resources:

how can we do it better?

Robin Waples

NOAA, robin.waples@noaa.gov

Andre E. Punt

University of Washington, aepunt@u.washington.edu

Jason M. Cope

Northwest Fisheries Science Center, jason.cope@noaa.gov

Follow this and additional works at: https://digitalcommons.unl.edu/usdeptcommercepub

Waples, Robin; Punt, Andre E.; and Cope, Jason M., "Integrating genetic data into management of marine resources: how can we do it better?" (2008). Publications, Agencies and Staff of the U.S. Department of Commerce. 455.

https://digitalcommons.unl.edu/usdeptcommercepub/455

This Article is brought to you for free and open access by the U.S. Department of Commerce at DigitalCommons@University of Nebraska - Lincoln. It has been accepted for inclusion in Publications, Agencies and Staff of the U.S. Department of Commerce by an authorized administrator of DigitalCommons@University of Nebraska - Lincoln. 


\title{
Integrating genetic data into management of marine resources: how can we do it better?
}

\author{
Robin S Waples ${ }^{1}$, André E Punt ${ }^{2}$ \& Jason M Cope ${ }^{3}$ \\ ${ }^{1}$ Northwest Fisheries Science Center, 2725 Montlake Blvd East, Seattle, WA 98112, USA; ${ }^{2}$ School of Aquatic and Fishery \\ Sciences, Box 355020, University of Washington, Seattle, WA 98195-5020, USA; ${ }^{3}$ Fishery Resource Analysis and \\ Monitoring Division, Northwest Fisheries Science Center, 2725 Montlake Blvd East, Seattle, WA 98112, USA
}

\begin{abstract}
Molecular genetic data have found widespread application in the identification of population and conservation units for aquatic species. However, integration of genetic information into actual management has been slow, and explicit and quantitative inclusion of genetic data into fisheries models is rare. In part, this reflects the inherent difficulty in using genetic markers to draw inferences about demographic independence, which is generally the information of the greatest short-term interest to fishery managers. However, practical management constraints, institutional structures and communication issues have also contributed to the lack of integration. This paper identifies some of the organizational, conceptual and technical barriers that have hampered full use of genetics data in stock assessment and hence fishery management and outlines how such use could be enhanced.
\end{abstract}

Keywords Demographic independence, fish stock assessment, fisheries management, mixed-stock fisheries, stock identification

\section{Correspondence:}

Robin Waples, Northwest Fisheries Science Center, 2725 Montlake Blvd East, Seattle, WA 98112, USA

Tel.: + 12068603254 Fax: + 12068603335 E-mail: robin.waples@ noaa.gov

Received 5 May 2008 Accepted 27 Aug 2008

$\begin{array}{lr}\text { Introduction } & \mathbf{4 2 4} \\ \text { Factors contributing to the problem } & \mathbf{4 2 5} \\ \text { Biological Realities } & 425 \\ \text { Identifying populations and stocks } & 425 \\ \text { Mixed-stock fishery analysis } & 428 \\ \text { Communication issues } & 429 \\ \text { Statistical significance vs. best available science } & 429 \\ \text { Disagreements and uncertainties among geneticists } & 430 \\ \text { Institutional issues } & 431 \\ \text { Mismatch between management units and biological units } & 431 \\ \text { Allocation issues } & 433 \\ \text { Organizational structure } & 434 \\ \text { An example - genetic stock identification of Chinook salmon } & \mathbf{4 3 4} \\ \text { Background } & 434 \\ \text { Biological and technical challenges } & 435 \\ \text { Institutional issues } & 435 \\ \text { Communication } & 435 \\ \text { Solutions: some strategies for improving the use of genetic data in fisheries management } & \mathbf{4 3 5} \\ \text { Communication } & 435\end{array}$ 


$\begin{array}{lr}\text { Integration } & 435 \\ \text { Improved dialogue } & 436 \\ \text { Getting real } & 437 \\ \text { Analytical methods } & 437 \\ \text { Institutional changes } & 438 \\ \text { Being opportunistic } & 438 \\ \text { Emerging areas where genetic information can improve fisheries management } & \mathbf{4 3 8} \\ \text { Management strategy evaluation } & 438 \\ \text { Novel applications } & 439 \\ \text { Population abundance } & 439 \\ \text { A global testing of genetic techniques for management purposes } & 441 \\ \text { Miscellaneous } & 441 \\ \text { Conclusions } & \mathbf{4 4 1} \\ \text { Acknowledgements } & \mathbf{4 4 2} \\ \text { References } & \mathbf{4 4 2} \\ \text { Appendix 1: Fred Utter's take on the genetic marker wars (unpublished data) } & \mathbf{4 4 8}\end{array}$

\section{Introduction}

Management of living marine resources involves modifying anthropogenic impacts to achieve societal goals. It is widely recognized that sound management depends on scientific information, and a variety of international organizations have been established to facilitate collection and interpretation of scientific data for marine species in a management context (e.g. International Council for the Exploration of the Sea, ICES; International Whaling Commission, IWC; International Commission for the Conservation of Atlantic Tunas, ICCAT; North Pacific Marine Science Organization, PICES). In the USA, the three laws with the greatest direct impact on fisheries management at the national level are the Magnusson-Stevens Fisheries Conservation and Management Act (MSA), the Endangered Species Act (ESA) and the Marine Mammal Protection Act (MMPA). Each of these acts has different (and potentially conflicting) goals, but all have a common need for scientific advice on the likely consequences of alternative management actions.

Much of the scientific advice for fisheries management is based on outputs of stock assessment models. Several texts (Hilborn and Walters 1992; Quinn and Deriso 1999; Haddon 2001; Walters and Martell 2004) describe the plethora of methods used for fisheries stock assessment, which differ with respect to data requirements, complexity and the quantities they are designed to estimate. However, all involve (to at least some extent) three steps: (i) fitting a model to data; (ii) using results of the model fitting exercise to make inferences about attributes of the population being assessed and (iii) using results of the population assessment to evaluate the ability of alternative management actions to satisfy management goals and objectives (which arise from legislation, international agreements and court decisions). In addition, all stock assessment methods require that the stocks/ populations to be assessed are defined.

Some of the most fundamental (and vexing) problems in marine resource management are amenable to study with genetic methods. For example, in the 1950s, dissatisfaction with performance of phenotypic methods for stock identification encouraged early exploration of the usefulness of genetic markers (reviewed by Cadrin et al. 2005). Identification of genetically based differences among populations spurred development of statistical algorithms that can provide estimates of contributions of source populations to a mixed-stock fishery (Milner et al. 1985). The field of fishery genetics has greatly expanded in recent decades (Sweijd et al. 2000; Ward 2000; Hauser and Carvalho 2008), in parallel with (and due in no small part to spin-offs from) rapidly developing technologies in the field of human genetics. A recent meeting reviewing six decades of fishery genetics included, among many others, talks on genetic variation in reaction norms in fish, fishery-induced selection, parentage analysis to evaluate relative reproductive success, genetic analysis of domestication, insights into population histories using DNA from archived scales, gene 
expression analyses to assess reproductive status, co-evolutionary relationships between IHNV virus and salmonid fishes and molecular tools for remote biosensing (see Waples et al. 2008 or http:// www.nwfsc.noaa.gov/events/workshops/index.cfm for a meeting summary and agenda). More broadly, genetic data are widely used in many aspects of global biodiversity conservation, including identification of species (Hebert et al. 2004; Smith et al. 2006) and conservation units (Waples 1991; Moritz 1994; Crandall et al. 2000) and management of captive or artificially propagated populations (Frankham et al. 2002; Ryder 2003).

It is therefore somewhat ironic that, in spite of the considerable needs for scientific information by managers of living marine resources, and in spite of the demonstrated ability of genetic data to address questions of direct management relevance, formal integration of genetic information into fisheries management has been slow in many cases and uneven in even the most favourable situations. For example, on the West Coast of the USA, there is a rather imperfect correlation between the population units of groundfish species that have been identified with genetic markers and the units that are used for stock assessments (Table 1), and similar patterns can be found elsewhere in the world. This paper explores some of the reasons why this has occurred, where and how genetic information is currently being used in fisheries management, and how better integration of genetic information and traditional methods of fisheries stock assessment could substantially improve the quality of management advice. This is a large topic, so in this paper we have chosen to focus primarily on two widespread uses for genetic information in providing management advice: identification of populations or stocks and analysis of mixed-stock fisheries. We illustrate with examples drawn primarily from our experiences with the management of fisheries and whaling off Australia, South Africa and the West Coast of North America.

\section{Factors contributing to the problem}

\section{Biological realities}

Identifying populations and stocks

Andrewartha and Birch (1984) identified two major ways of thinking about populations: the ecological paradigm and the evolutionary paradigm (see Waples and Gaggiotti 2006 for more discussion).
Both paradigms invoke a cohesive force that unites individuals. In the ecological paradigm, the cohesive forces are demographic; a population is characterized by individuals that co-occur in space and time and have an opportunity to interact demographically. Important linkages between populations can largely be captured by the migration rate, $m$, which is the fraction of individuals in one population that were born in another population. The ecological paradigm is a natural way to approach the problem of defining populations or stocks because managers are typically interested primarily in population dynamic processes. One of the most common management problems is to identify populations that are demographically independent and can be modelled as separate entities. Information that indicates whether migration between two putative populations is low enough that they can be considered to be demographically independent (or, conversely, whether migration is high enough that they should be treated as a single demographic unit) is therefore of considerable interest to managers.

In the evolutionary paradigm, the cohesive forces are genetic; a population is characterized by individuals that interbreed. Most population genetic models are sensitive to the combined parameter $m N_{\mathrm{e}}$, where $N_{\mathrm{e}}$ is the effective population size. The product $m N_{\mathrm{e}}$ represents the effective number of migrants per generation (roughly, those that actually reproduce and contribute genes to the new generation). This parameter is a key one in evolutionary biology; for example, it is central to Wright's (1931) famous equation that relates a measure of population genetic differentiation $\left(F_{\mathrm{ST}}\right)$ to the level of gene flow:

$F_{\mathrm{ST}} \approx 1 /\left(1+4 m N_{\mathrm{e}}\right), \quad m N_{\mathrm{e}} \approx\left(1 / F_{\mathrm{ST}}-1\right) / 4$.

$F_{\text {ST }}$ is easy to estimate in natural populations from samples analysed for molecular markers. Although Equation (1) is based on a simple, equilibrium model and assumptions that are rarely satisfied by natural populations (Waples 1998; Whitlock and McCauley 1999; Hedgecock et al. 2007), it still can provide useful insights into levels of population differentiation, and this equation (or variations thereof) has been widely used in studying patterns of connectivity in marine and terrestrial systems. However, the estimation of $m N_{\mathrm{e}}$, is of little direct use to managers, who (as noted above) are generally interested in $m$. A consequence of these contrasting paradigms (ecological and demographic) is that, although 
Genetic data and fisheries management $R S$ Waples et al.

Table 1 Genetic population structure and stock assessment units for West Coast groundfishes.

\begin{tabular}{|c|c|c|c|c|}
\hline \multirow[b]{2}{*}{ Species } & \multirow[b]{2}{*}{ Common name } & \multicolumn{2}{|r|}{ Genetics } & \multirow[b]{2}{*}{ Stock assessment units } \\
\hline & & Marker & Stock substructure & \\
\hline \multicolumn{5}{|l|}{ Nearshore } \\
\hline Hexagrammos decagrammus & Kelp greenling & NA & NA & 2 units: $C A$ and $\mathrm{OR}^{\mathrm{a}}$ \\
\hline Ophiodon elongatus & Lingcod & al & $\begin{array}{l}2 \text { stocks: PS stock and coastal } \\
\text { stock }(\mathrm{CA} \text { to } A K)^{1}\end{array}$ & $\begin{array}{l}2 \text { units: above and below } \\
43^{\circ} \mathrm{N}^{\mathrm{b}}\end{array}$ \\
\hline Platichthys stellatus & Starry flounder & NA & NA & 2 units: $\mathrm{CA}$ and $\mathrm{OR} / \mathrm{WA}^{\mathrm{c}}$ \\
\hline Scorpaena guttata & California scorpionfish & NA & NA & 1 unit: S. of Pt. Conception ${ }^{d}$ \\
\hline Scorpaenichthys marmoratus & Cabezon & $\mathrm{mt}$ & $\begin{array}{l}\text { Minimum } 2 \text { stocks: } N \text {. and } S \text {. of } \\
\text { Fort Bragg, CA; up to } 8 \\
\text { stocks: WA, OR, and } 6 \text { in } \mathrm{CA}^{2}\end{array}$ & $\begin{array}{l}1 \text { unit: C. CA to N. } \mathrm{CA}^{\mathrm{e}} \\
2 \text { CA units: N. and S. of Pt. } \\
\text { Conception }\end{array}$ \\
\hline Sebastes carnatus & Gopher rockfish & $\mathrm{ms}$ & No structure in $\mathrm{CA}^{3}$ & $\begin{array}{l}1 \text { unit: CA (N. of Pt. } \\
\text { Conception) }\end{array}$ \\
\hline \multirow[t]{6}{*}{ Sebastes melanops } & Black rockfish & al & $\begin{array}{l}2 \text { stocks: WA to mid-OR; } \\
\text { mid-OR to } \mathrm{CA}^{4}\end{array}$ & $\begin{array}{l}1 \text { unit: } n . O R \text { to } W A^{h} \\
1 \text { unit: } C A \text { to } O R^{i, j}\end{array}$ \\
\hline & & al & $\begin{array}{l}3 \text { stocks: WA to n. OR, n. OR } \\
\text { to n. CA north, n. CA south }{ }^{5}\end{array}$ & \\
\hline & & al & None $\mathrm{b} / \mathrm{t} \mathrm{OR}$ and $W A^{6}$ & \\
\hline & & $\mathrm{ms}$ & 2 stocks: WA; southern $\mathrm{OR}^{7}$ & \\
\hline & & $\mathrm{ms}$ & $\begin{array}{l}2 \text { stocks: w AK to Yakutat; } \\
\text { Yakutat to WA }\end{array}$ & \\
\hline & & $\mathrm{ms}$ & $\begin{array}{l}2 \text { stocks: w. AK to Yakutat; } \\
\text { Continental U.S; and a } \\
\text { Brookings, OR outlier }\end{array}$ & \\
\hline Sebastes miniatus & Vermilion rockfish & $\mathrm{ms}$ & $\begin{array}{l}\text { Cryptic speciation segregated } \\
\text { by depth (break at } 100 \mathrm{~m} \text { ); } \\
\text { Deeper species primarily } \\
\text { south of Pt. Conception, } \mathrm{CA}^{10}\end{array}$ & $\begin{array}{l}2 \text { unit: } \mathrm{N} \text {. and S. of Pt. } \\
\text { Conception, } \mathrm{CA}^{\mathrm{k}}\end{array}$ \\
\hline \multirow[t]{3}{*}{ Sebastes mystinus } & Blue rockfish & $\mathrm{mt}$ & $\begin{array}{l}2 \text { stocks: N. of Mendocino, CA; } \\
\text { S. of Mendocino, } \mathrm{CA}^{11}\end{array}$ & 1 unit: Pt. Conception to OR' \\
\hline & & $\mathrm{ms}$ & $\begin{array}{l}\text { None b/t San Miguel, CA and } \\
\text { Fort Bragg, } \mathrm{CA}^{12}\end{array}$ & \\
\hline & & $\mathrm{mt} ; \mathrm{ms}$ & Two incipient types ${ }^{13}$ & \\
\hline \multicolumn{5}{|l|}{ Shelf/slope } \\
\hline Anoplopoma fimbria & Sablefish & NA & NA & $\begin{array}{l}2 \text { unit: above and below } 43^{\circ} \mathrm{N}^{\mathrm{m}} \\
1 \text { unit: } C A \text { to } W A^{\mathrm{n}, \mathrm{o}}\end{array}$ \\
\hline Atheresthes stomias & Arrowtooth flounder & NA & NA & 1 unit: $C A$ to $W^{p}$ \\
\hline Eopsetta jordani & Petrale sole & NA & NA & $\begin{array}{l}3 \text { units: (1) above } 43^{\circ} \mathrm{N} \text { lat.; (2) } \\
43^{\circ} \mathrm{N} \text { to } 40^{\circ} 10^{\prime} \mathrm{N} \text {; (3) below } \\
40^{\circ} 10^{\prime} \mathrm{N}^{\mathrm{q}} \\
2 \text { units: above and } \\
\text { below } 43^{\circ} \mathrm{N}^{\mathrm{r}}\end{array}$ \\
\hline Microstomus pacificus & Dover sole & $\mathrm{mt}$ & $\begin{array}{l}\text { Substructuring found from AK } \\
\text { to } \mathrm{CA} \text {, but no consistent } \\
\text { geographic groupings }{ }^{14}\end{array}$ & 1 unit: $C A$ to $W A^{s, t}$ \\
\hline Parophrys vetulus & English sole & NA & NA & $\begin{array}{l}1 \text { unit (CA to WA), but } 2 \\
\text { fisheries (break near Cape } \\
\text { Mendocino) }\end{array}$ \\
\hline \multirow[t]{3}{*}{ Merluccius productus } & Pacific hake & al & 2 stocks: coastal and $\mathrm{PS}^{15}$ & 1 unit: $C A$ to $W A^{v}$ \\
\hline & & al & $\begin{array}{l}2 \text { stocks divided at } 28^{\circ} \mathrm{N} \\
(\text { Baja CA })^{16}\end{array}$ & \\
\hline & & al & $\begin{array}{l}3 \text { stocks: coastal, PS, and Strait } \\
\text { of Georgia }^{17}\end{array}$ & \\
\hline
\end{tabular}


Table 1 Continued.

\begin{tabular}{|c|c|c|c|c|}
\hline \multirow[b]{2}{*}{ Species } & \multirow[b]{2}{*}{ Common name } & \multicolumn{2}{|r|}{ Genetics } & \multirow[b]{2}{*}{ Stock assessment units } \\
\hline & & Marker & Stock substructure & \\
\hline Raja rhina & Longnose skate & NA & NA & 1 unit: $C A$ to $W A^{w}$ \\
\hline $\begin{array}{l}\text { Sebastolobus } \\
\text { alascanus }\end{array}$ & $\begin{array}{l}\text { Shortspine } \\
\text { thornyhead }\end{array}$ & $\begin{array}{l}\text { al } \\
\mathrm{mt} \\
\mathrm{mt}\end{array}$ & $\begin{array}{l}\text { None from } A K \text { to } C A^{18} \\
3 \text { stocks: } A K, C A \text {, and Cortez Bank }{ }^{19} \\
\text { Substructuring found from } A K \text { to } C A \text {, } \\
\text { but no consistent geographic } \\
\text { groupings }^{20}\end{array}$ & 1 unit: $C A$ to $W A^{x}$ \\
\hline Sebastolobus altivelis & Longspine thornyhead & $\mathrm{mt}$ & $\begin{array}{l}\text { Substructuring found from AK to CA, } \\
\text { but no consistent geographic } \\
\text { groupings }^{20}\end{array}$ & 1 unit: $C A$ to $W A^{y}$ \\
\hline \multirow[t]{3}{*}{ Sebastes alutus } & Pacific Ocean perch & al & $\begin{array}{l}3 \text { stocks: Gulf of AK; WA \& OR; Prince } \\
\text { William Sound }{ }^{21}\end{array}$ & 1 unit: $O R$ to $W A^{z}$ \\
\hline & & al & $\begin{array}{l}\text { Low differentiation between AK \& } \\
\text { WA }^{22}\end{array}$ & \\
\hline & & $\mathrm{ms}$ & $\begin{array}{l}\text { 3 BC stocks: Vancouver I.; E. Queen } \\
\text { Charlotte; W. Queen Charlotte }\end{array}$ & \\
\hline Sebastes crameri & Darkblotched rockfish & $\mathrm{ms}$ & $\begin{array}{l}\text { Low but significant differentitaion from } \\
\text { N. CA to WA; no geographic } \\
\text { groupings }^{24}\end{array}$ & $\begin{array}{l}1 \text { stock: } 36^{\circ} \mathrm{N} \text { to Canadian } \\
\text { boarder }^{\text {aa }}\end{array}$ \\
\hline Sebastes diploproa & Splitnose rockfish & NA & NA & 1 stock: $C A$ to $W A^{b b}$ \\
\hline Sebastes entomelas & Widow rockfish & NA & NA & 1 stock: $C A$ to $W A^{c c}$ \\
\hline \multirow[t]{3}{*}{ Sebastes flavidus } & Yellowtail rockfish & al & None from $W A$ to $\mathrm{CA}^{21}$ & $\begin{array}{l}3 \text { units: } 40^{\circ} 30^{\prime} \mathrm{N} \text { to } 45^{\circ} 46^{\prime} \mathrm{N} \text {; } \\
45^{\circ} 46^{\prime} \mathrm{N} \text { to } 47^{\circ} 20^{\prime} \mathrm{N} \text {; } \\
47^{\circ} 20^{\prime} \mathrm{N} \text { to } 49^{\circ} \mathrm{N}^{\text {dd }}\end{array}$ \\
\hline & & & None b/t Vancouver I., WA \& $\mathrm{CA}^{25}$ & \\
\hline & & $\mathrm{mt} ; \mathrm{ms}$ & $\begin{array}{l}2 \text { stocks: N. of Cape Mendocino, CA; } \\
\text { S. of Cape Mendocino, } \mathrm{CA}^{9}\end{array}$ & \\
\hline Sebastes goodei & Chilipepper & al & None from WA to $\mathrm{CA}^{21}$ & 1 unit: $C A$ to $O R^{e e}$ \\
\hline Sebastes jordani & Shortbelly rockfish & $\mathrm{ms}$ & $\begin{array}{l}\text { None from San Diego, } \mathrm{CA} \text { to Cape } \\
\text { Mendocino, } \mathrm{CA}^{26}\end{array}$ & 1 unit in $C A^{f f}$ \\
\hline Sebastes levis & Cowcod & NA & NA & 1 unit: southern $\mathrm{CA}^{\mathrm{gg}}$ \\
\hline Sebastes melanostomus & Blackgill rockfish & NA & NA & 1 unit: $\mathrm{CA}^{\text {hh }}$ \\
\hline Sebastes paucispinis & Bocaccio & al & $\begin{array}{l}\text { None from } \mathrm{OR} \text { to } \mathrm{CA}^{21} \\
\text { Ambiguous structure; most consistent } \\
\text { above and below Pt. Conception, } \mathrm{CA}^{27}\end{array}$ & 1 unit: S. and C. $\mathrm{CA}^{\mathrm{ii}}$ \\
\hline Sebastes pinniger & Canary rockfish & al & 2 stocks: WA to S. OR; S. OR to $\mathrm{CA}^{21}$ & 1 unit: $C A$ to $W A^{i j}$ \\
\hline Sebastes ruberrimus & Yelloweye rockfish & $\mathrm{ms}$ & 2 stocks: WA to OR; $\mathrm{PS}^{28}$ & 1 unit: $C A$ to $W A^{k k}$ \\
\hline Sebastes rufus & Bank rockfish & NA & NA & $\begin{array}{l}1 \text { unit: } C A \text { to WA" } \\
1 \text { unit: } \mathrm{CA}^{\mathrm{mm}}\end{array}$ \\
\hline
\end{tabular}

NA, not available; al, allozymes; ms, microsatellites; mt, mitochondrial DNA; rflp, restriction fragment length polymorphism; AK, Alaska; BC, British Columbia; CA, California; OR. Oregon; PS, Puget Sound; WA, Washington.

1 Jagielo et al. (1996); ${ }^{2}$ Villablanca \& Nakamura (2007); ${ }^{3}$ Narum et al. (2004); ${ }^{4}$ Baker, unpublished data; ${ }^{5}$ Wallace et al. (1999); ${ }^{6}$ Baker (1999); ${ }^{7}$ Miller et al. (2005); ${ }^{8}$ L. Seeb and J. Seeb, unpublished data; ${ }^{9}$ Hess, unpublished data; ${ }^{10}$ Hyde et al. (2008); ${ }^{11}$ Cope (2004); ${ }^{12}$ Burford and Larson (2007); ${ }^{13}$ Burford and Bernardi (2008); ${ }^{14}$ Stepien (1999); ${ }^{15}$ Utter and Hodgins (1969), (1971); ${ }^{16}$ Vrooman \& Paloma (1977); ${ }^{17}$ Iwamoto et al. (2004); ${ }^{18}$ Siebenaller (1978); ${ }^{19}$ Stepien (1995); ${ }^{20}$ Stepien et al. (2000); ${ }^{21}$ Wishard et al. (1980); ${ }^{22}$ Seeb \& Gunderson (1988); ${ }^{23}$ Withler et al. (2001); ${ }^{24} \mathrm{Gomez}-$ Uchida \& Banks (2005); ${ }^{25} \mathrm{McGauley} \mathrm{\&} \mathrm{Mulligan} \mathrm{(1995);}{ }^{26} \mathrm{Constable}$ (2006); ${ }^{27}$ Matala et al. (2004); ${ }^{28}$ Wallace et al. (2006).

${ }^{\mathrm{a} C}$ Cope and MacCall (2005); ${ }^{\mathrm{b}} \mathrm{Jagielo}$ and Wallace (2005); ${ }^{\mathrm{c}}$ Ralston (2005); ${ }^{\mathrm{d}}$ Maunder et al. (2005); ${ }^{\mathrm{e}}$ Cope et al. (2004); ${ }^{\mathrm{f}}$ Cope \& Punt (2005); ' 'Key et al. (2005); 'Wallace et al. (1999); 'Ralston \& Dick (2003); 'Sampson (2007); 'MacCall (2005); 'Key et al. (2008); 'methot and Hightower (1990); ${ }^{\mathrm{n}}$ Methot (1992); ${ }^{\circ}$ Schirripa 2007; ${ }^{P}$ Kaplan \& Helser (2007); ' $\mathrm{S}$ Sampson and Lee (1999); 'Lai et al. (2005); sSampson (2005); 'Sampson \& Wood (2001); " Stewart (2005); ' ${ }^{\mathrm{N}}$ Helser \& Martell (2007); ${ }^{\mathrm{w}}$ Gertseva \& Schirripa (2007); ${ }^{\mathrm{x}} \mathrm{Hamel}$ (2005b); y Fay (2005); ${ }^{\mathrm{Y}} \mathrm{Hamel}$ (2005a); ${ }^{\text {aa }} \mathrm{Hamel}$ (2007); ${ }^{\mathrm{bb}}$ Rogers (1994); ${ }^{\mathrm{cc}} \mathrm{He}$ et al. (2005); ${ }^{\mathrm{dd}}$ Wallace and Lai (2005); ${ }^{\text {ee }}$ Field (2007); ${ }^{\mathrm{ff}}$ Field et al. (2007); ${ }^{99}$ Dick et al. (2007); ${ }^{\text {hh }}$ Helser (2005); "MacCall (2005); ijStewart (2007); ${ }^{\mathrm{kk}}$ Wallace et al. (2006); "Pearson (1994); ${ }^{\text {mm} P i n e r ~ e t ~ a l . ~}$ (2000). 
fishery managers need information about migration, and genetic data can provide information about migration, it is not in a currency that is immediately useful to managers.

A second difficulty is that the transition between demographic dependence and independence occurs at a level of migration that is very high in evolutionary terms. Surprisingly, little attention in the literature has been paid to assessing the level of migration required to produce demographic coupling, but one simulation study (Hastings 1993) suggests that this might occur at about $m=0.1$ : populations connected by $10 \%$ or more migration are demographically coupled, whereas those experiencing less migration are demographically independent. Under what circumstances could genetic data distinguish between migration rates of, say, $5 \%, 10 \%$ and $20 \%$ - that is, half, equal to or twice the putative threshold for demographic independence? When populations are small $\left(N_{\mathrm{e}} \approx 100\right)$, these different migration scenarios have substantially different expected values of $F_{\mathrm{ST}}$ (Fig. 1). However, populations of most marine species are large and might have effective sizes of order $10^{3}$ or higher, even allowing for relatively small ratios of effective size to census size (Hauser and Carvalho 2008). As illustrated in Fig. 1, for $N_{\mathrm{e}}>10^{3}$ the expected value of $F_{\mathrm{ST}}$ is extremely small for $m>0.05$. This means that it is a very challenging task to use genetic data to distinguish between migration rates that do and do not lead to demographic independence, particularly given all the potential sources of noise (e.g.

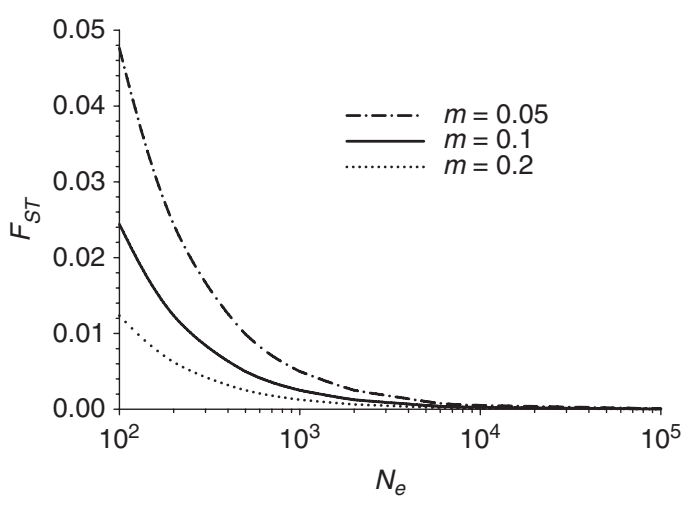

Figure 1 Expected equilibrium value of genetic differentiation $\left(F_{\mathrm{ST}}\right)$ for Wright's island model as a function of effective population size $\left(N_{\mathrm{e}}\right)$. Unless $N_{\mathrm{e}} \ll 10^{4}$, genetic methods have little power to distinguish migration rates half, equal to or twice the putative threshold for demographic independence (migration rate, $m=0.1$ ). departures from random sampling; genotype scoring or recording errors) that could affect results (Waples 1998).

An important consequence of this reality is an asymmetry in the ability of equilibrium genetic methods to provide useful information regarding stock structure. If two putative populations really are connected by only low levels of migration, then (provided adequate samples can be collected) genetic methods generally will have considerable power to demonstrate this. However, if migration rates are high, genetic methods typically will struggle to distinguish between levels of connectivity that are and are not consistent with the need for separate stock management. That is, geneticists often can say quite confidently, 'Yes, the evidence strongly points to more than one stock', but it is very difficult, based on genetic data alone, to say something like, 'Yes, we are convinced that the two putative populations are connected by high enough levels of migration that they are demographically coupled'.

Taken together, these two biological realities pose considerable challenges to those wishing to use population genetic data to draw inferences of management relevance about population demography.

\section{Mixed-stock fishery analysis}

Populations or stocks that do not interbreed to any appreciable degree can nevertheless intermingle during part of their life cycle (e.g. on feeding grounds or during migrations), and effectively managing these mixed harvests to take advantage of abundant populations without overharvesting at-risk populations is one of the most challenging management problems for many aquatic species. Methods that take advantage of naturally occurring genetic markers have attracted a good deal of attention because application of physical tags is very labour intensive, and biological markers, such as scale patterns, can vary dramatically from year to year. The first genetic stock identification (GSI) methods for estimating the contributions of two or more stocks to a mixed harvest were developed in the late 1970s and applied to salmon (Grant et al. 1980; Milner et al. 1985). Since then, the rapidly expanding availability of highly variable genetic markers and refinements in statistical analyses (Pella and Milner 1987; Smouse et al. 1990; Pella and Masuda 2001; Koljonen et al. 2005) have considerably increased the ability to assess the proportions of different stocks in a mixed-stock 
assemblage. Applications to a number of species have shown that these methods can provide information of direct management relevance (Utter et al. 1987; Brown et al. 1996; Beacham et al. 1999, 2004; Potvin and Bernatchez 2001). However, such information has not always been fully incorporated into fishery management. As discussed below in the example, this can be attributed in part to institutional and historical issues, but it also reflects the biological reality that the ability to resolve mixtures involving closely related populations can be limited.

\section{Communication issues}

Statistical significance vs. best available science Many geneticists come from a hypothesis-testing background; a typical study design is to take samples of individuals from different localities and test whether one can reject the null hypothesis that the samples were drawn from a single, panmictic population. The hypothesis-testing framework is well suited to many types of scientific inquiry, where few or no practical consequences might ensue from making a type II error (failing to detect a true effect). In that case, it can be reasonable to stipulate a low $\alpha$ level to keep the type I error (false positive) rate low. Unfortunately, this approach has limited usefulness for fishery management, even though it is well grounded in statistical methodology. This is because the probability of obtaining a statistically significant result (power to reject the null hypothesis when it is false) depends not only on the effect size (true level of population differentiation - the biological signal of interest), but also on the amount of data (numbers of individuals, loci and alleles per locus). With limited data, important biological differences might be missed because of a lack of statistical power (Martien and Taylor 2003). Conversely, with modern techniques it might be possible to demonstrate that very small genetic differences are statistically significant, even if they are too small to be biologically meaningful in a particular context (Waples 1998).

More generally, a statistical test of panmixia is not often of much use to decision makers by itself. In most cases, there are sound biological reasons for believing that individuals from location A are more likely to breed with other individuals from location A than they are with individuals from location B. If that is true, then with sufficient effort it eventually will be possible to show that allele frequencies are not identical in the two areas. What managers really want to know is how much more likely is local interbreeding than migration. This is directly related to the true level of population differentiation, or effect size. Notably, a $P$-value from a statistical test does not provide any information about effect size. Furthermore, in natural resource management, there can be severe (perhaps irreversible) consequences of making a type II error (e.g. failing to detect population structure when it exists). As a consequence, fishery scientists and managers typically work on the basis of 'best available science', in which various lines of evidence (including $P$-values and effect sizes, as well as associated sources of uncertainty and any other related information) are considered in an overall context before making a management decision. Application of 'best available science' approaches are designed to avoid some of management mistakes of the past, where, for example, fisheries managers sometimes assumed a null hypothesis of 'no depletion' and only acted to constrain fisheries if that hypothesis could be convincingly rejected.

Stock assessments of school shark (Galeorhinus galeus, Triakidae), which is considered overfished off Australia but sustainably harvested off New Zealand, illustrate these contrasting philosophies. Tagging studies document some migration between the two areas (Hurst et al. 1999), and at best weak evidence for genetic differentiation $\left(F_{\mathrm{ST}}=0.0014\right.$ for allozymes and 0.0016 for mtDNA; both $P>0.05)$ has been found between school sharks in Australia and New Zealand (Ward and Gardner 1997; R.D. Ward, personal communication). Although the genetic analyses could not reject the hypothesis of a single stock at the nominal $\alpha=0.05$ level, the school shark populations in the two countries are assessed and managed separately (Punt et al. 2000). This is done because the weight of evidence from the genetics data (a Bayesian analysis in which the one- and two-stock hypotheses are assigned equal prior probability) and tagging data (which suggest only low rates of movement between Australia and New Zealand and that only 'sub-adult' school sharks tagged in New Zealand had been recaptured in Australia) lend relatively more support to the hypothesis of two populations. Furthermore, treating Australian and New Zealand school sharks separately is more precautionary for the species in Australia because if the assumption were made that there is only one stock, there might have been no reason to reduce 
harvest rates in Australia. It should be noted that, in this particular case, separate management (and assessment) would probably occur simply for administrative and logistical reasons because fish from one species are managed by two different national jurisdictions and hence under different objectives and legislation. It should also be noted that always treating putative population as separate stocks for assessment and management purposes is not always precautionary and that doing so unnecessarily can lead to loss of yield.

Disagreements and uncertainties among geneticists As is typical of any rapidly evolving scientific discipline, evolutionary biology is characterized by energetic discussions among practitioners regarding the best approaches for experimental design, laboratory techniques, data interpretation and statistical and analytical methods. Inevitably, disagreements arise among scientists on some of these key issues. Although this is a natural part of the scientific process and can be a healthy way of advancing the field, real or perceived disagreements among geneticists can be confusing and troubling to managers, as can occasional publications that question the basic premise of applying genetic principles to conservation and management (Gauldie 1991; Backman and Berg 1992; Cronin 2007).

The genetic 'marker wars' of the past several decades are a case in point. For many years, allozymes were the universal workhorse genetic makers, and they made many valuable contributions to basic and applied conservation and management. Around 1980, the first applications of mitochondrial DNA (mtDNA) analysis to natural populations were published, and it was not long before some predicted that mtDNA would completely replace allozymes and provide answers to all key management questions regarding stock structure. Although mtDNA has indeed provided a wealth of new insights, it is not a panacea and has some limitations with respect to fishery management (e.g. it is clonal and maternally inherited, so provides no information about male migration or gene flow, and it is only a single marker and hence has much less power for some applications than a full suite of nuclear markers). In the 1990s, microsatellites muscled aside mtDNA and largely replaced allozymes as the markers of choice for population genetics studies. These highly variable markers have provided greatly increased power and opened up exciting new opportunities (e.g. parent- age analysis and individual assignments) that were generally not feasible with allozymes or mtDNA. Again, some touted microsatellites as the silver bullet geneticists needed to answer management questions. However, microsatellites have not made (and cannot make) the biological realities discussed above go away. Managers who remember the overzealous promotion by some of mtDNA or microsatellites are understandably sceptical of subsequent (valid) claims by geneticists for the potential of new methods.

Now the field seems poised to shift toward another type of marker, single-nucleotide polymorphisms (SNPs; Morin et al. 2004a, Hauser and Seeb 2008). Like allozymes, SNPs are generally diallelic, so each marker has less power than a single microsatellite locus. However, they occur in vast numbers throughout the genome; therefore, eventually large overall increases in power are possible. Furthermore, once developed, SNPs can be assayed more reliably and cheaply than microsatellites, which could be a considerable advantage in largescale fishery management applications. However, development of sufficient numbers of SNP markers will be neither easy nor cheap, and analytical issues such as minimizing ascertainment bias (Clark et al. 2005) remain to be resolved. As a consequence, scientists hold diverse views on the best approach to take in the near future. Given uncertainties or disagreements among geneticists on such fundamental issues, it is not surprising that managers often elect to take a wait-and-see approach and defer major investments in genetic methodology until the situation has been clarified (see example below).

A related issue pertains to exciting opportunities provided by new analytical and statistical methods in population genetics. To take just one example, a nagging problem for genetic stock identification is a lack of certainty whether all populations contributing to the mixed harvest are represented in the genetic baseline. If not, the resulting stock composition estimates will be biased. An early attempt to address this problem (Smouse et al. 1990) provided a way to estimate contributions from a single population not included in the baseline. In the current decade, much more powerful and much more general genetic clustering programmes have been developed (Pritchard et al. 2000; Corander et al. 2004; Pella and Masuda 2006) which do not require any baseline data at all. These programmes attempt to identify component gene pools by form- 
ing groups of individuals that minimize single-locus (Hardy-Weinberg) and multiple-locus (linkage) disequilibrium within groups, using only the multilocus genotypic information in a mixed sample. The new clustering programmes have been widely used, both in academic and applied management contexts, and are remarkably powerful in some situations. Indeed, the potential ability to identify multiple gene pools in a single sample, without a priori assumptions about the relationship between sample location and population membership, is of considerable management interest. However, power of these methods is not unlimited, and their ability to provide meaningful information when levels of population genetic differentiation are weak (as occurs with many marine species) has not been rigorously studied (Hauser et al. 2006; Latch et al. 2006; Waples and Gaggiotti 2006; Schwartz and McKelvey 2008). It is difficult to develop solid recommendations for appropriate uses in applied management contexts because rigorous evaluation of programme performance has not been conducted at low levels of genetic differentiation. Population geneticists have a range of views on this issue, as evidenced by heated discussions at some recent meetings of the Scientific Committee of the IWC (IWC SC) (IWC 2007a). Healthy discussions like this can ultimately promote successful implementation of genetic methods into fishery management, but only if the technical issues are worked through in a logical, transparent and systematic way. The longer the debates continue without this sort of resolution, the more disenchanted managers are likely to be with geneticists and genetic methods in general.

Sometimes multiple genetic studies produce conflicting results. In the case of the black rockfish (Sebastes melanops, Sebastidae), Wallace et al. (1999) suggested separate genetic stocks north and south of Cape Falcon, Oregon, while Baker (1999) found that samples from north and south of Cape Falcon were quite similar (Table 1). The studies had different sampling and experimental designs; so, without additional information it is difficult to determine which provides a more accurate picture of stock structure. Changes to the population structures underlying a stock assessment can have profound implications for stock status regionally and hence for management actions. Assessments of hoki (Macruronus novazelandie, Macruronidae) off New Zealand have considered one- and two-stock scenarios (Francis 2006). The possibility of two ('western' and 'eastern') stocks is supported by consistent differences seen in morphometric and ageing studies (Livingston et al. 1992; Horn and Sullivan 1996; Livingston and Schofield 1996), but early genetic studies did not identify significant differences (Smith et al. 1981). The stock status is sufficiently different between assessments based on one- and two-stock scenarios potentially to be consequential for management decision making.

\section{Institutional issues}

Institutional uncertainty relates to the inability of institutional structures that underlie fisheries management to deal with the problems they confront (and how those problems change over time). Management systems in many jurisdictions have evolved from supporting development and expansion of fisheries and fishing fleets to focusing on conservation and sustainable utilization, but this transition has not always been smooth.

Mismatch between management units and biological units

The purpose of a stock assessment is to provide timely and appropriate scientific advice to management (see, for example, Fig. 2, which outlines the assessment and management process for federally managed species off the West Coast of the USA). Stock assessments always involve simplifications and assumptions that relate not only to biology, but also to the realities of providing management advice. In this section, we will focus on potential mismatches between units on which assessments and management are based and those inferred from biological data, but similar consideration apply for related issues. For example, assessments are almost always conducted for single species, whereas in reality stocks are influenced by multi-species effects. However, in the absence of accepted data and models for multi-species interactions, stock assessments will continue to be based on single-species models, the behaviour and data needs for which are well known and familiar to managers.

Stock assessments are generally based on a variety of sources of information, including catches, trends in abundance and size and/or age structure. Sampling designs for these data sources are often based on political or administrative boundaries. For example, data for groundfish species off the US West Coast are generally organized into regions defined by the International North Pacific Fisheries Commission (NPFMC), while management often occurs 


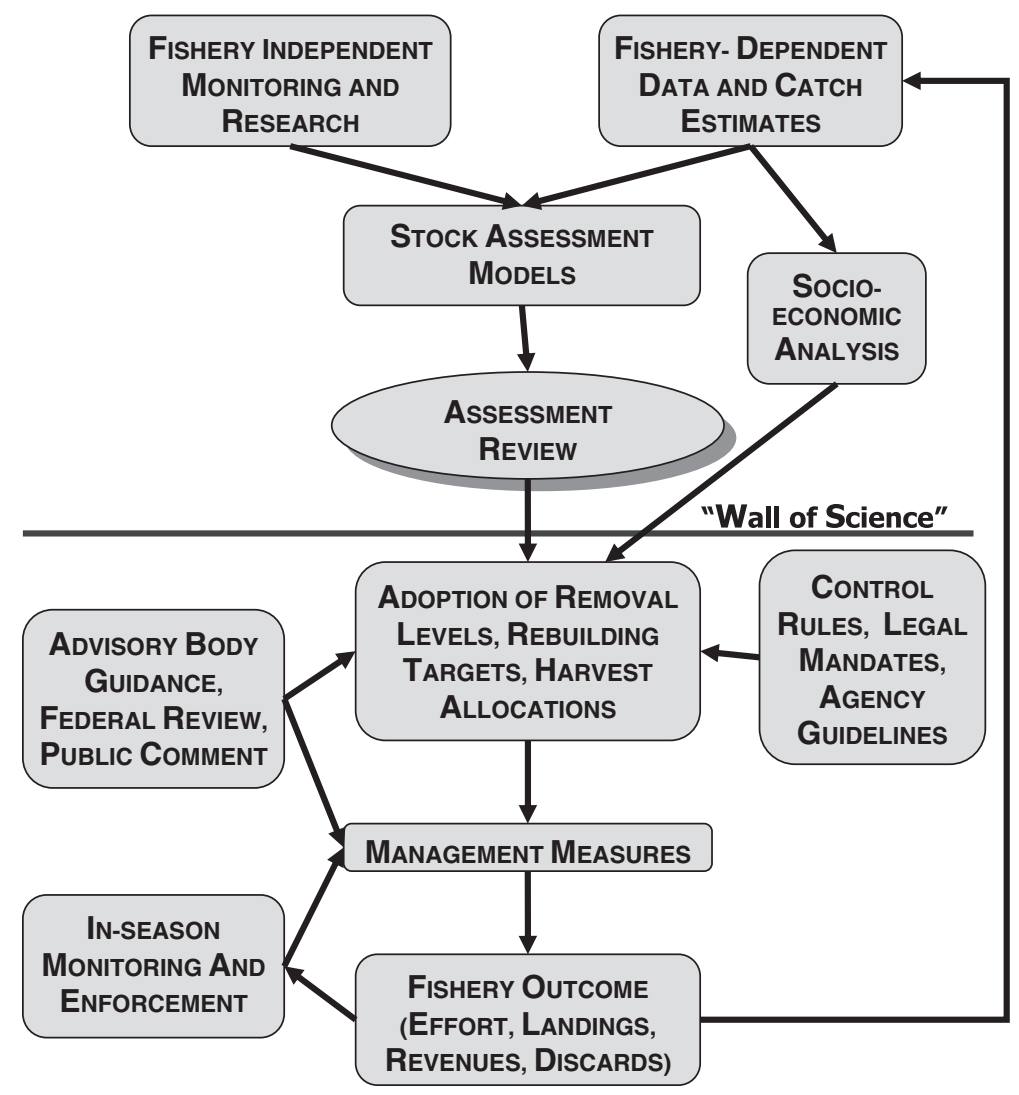

Figure 2 Overview of the management decision making and scientific advice processes for the fisheries managed by the Pacific Fishery Management Council (modified from Field et al. 2006, with permission).

at state (California, Oregon and Washington) levels and almost always along national lines (management arrangements for US West Coast groundfish can be very different between the USA, Canada and Mexico). The 2007 assessment of black rockfish S. melanops (Sebastidae, Wallace et al. 2007; Sampson 2007) involved an assessment boundary at Cape Falcon, OR, rather than at the Columbia River because Cape Falcon was the boundary for which most of the data were available. Had the Columbia River between chosen as the assessment boundary, it would have been difficult, if not impossible, to partition historical catches collected based on NPFMC boundaries to the new regions. Not surprisingly, the resulting discrepancy between biological and assessment boundaries can be frustrating for geneticists and managers alike.

Several factors probably contribute to the common mismatch between biological and management units evident in Table 1. The sampling design of genetic studies does not always match the geographic regions to which management controls are applied. In addition, as noted above, different genetics studies sometimes give conflicting results, or are presented in a format or currency (e.g. $P$-values or estimates of gene flow) that is not very useful to managers. Finally, sometimes population structure identified using genetic methods is difficult to reconcile with standard stock structure models. This can happen, for example, if genetic methods find a clinal pattern, where genetic affinities change gradually over distance rather than with discrete breaks (Table 1). Although one might define an arbitrary boundary (or boundaries) within the range of a species that exhibits clinal structure and estimate migration between the putative stocks so defined, this would require information on movement which is not available for the vast bulk of marine species.

A more extreme form of the mismatch between biology and management units occurs when genetic data indicate that there are multiple species (rather than just stocks) in a putative managed species. For example, an assessment of blue rockfish (Sebastes 
mystinus, Sebastidae) was conducted, even though genetic and other evidence suggests that two species are involved (Key et al. 2008, Table 1). This assessment combined data for the putative species because it is currently (and probably always will be) impossible to split the historical catches to species. Although conducting aggregate assessments is not ideal from a management viewpoint, it is better than not providing any management advice at all. Furthermore, simulation studies (Punt 1992) have shown that management objectives can be achieved if two stocks are assessed and managed as one, provided that the inherent productivity of the two stocks is similar and the catches by species reflect the relative abundance of each stock. A similar situation exists with the deepwater and Acadian redfish (Sebastes mentella and S. fasciatus, Sebastidae) from Atlantic waters of Canada. Although genetic data confirm these two closely related species are distinct (Sévigny et al. 2003), they are nearly impossible to tell apart in the field. As a consequence, although these redfish are managed separately in nine different areas of the North Atlantic, within each of the broad areas of sympatry (including the Gulf of St Lawrence, Laurentian Channel, Grand Banks and southern Labrador Sea), the two species are jointly managed as a single 'stock' (Morin et al. 2004b).

A different type of mismatch between biological and management units can arise from managing fisheries on a more regional basis. Interest in this approach has been spurred recently by two factors: (i) community-based efforts to collect more information on local stocks and (ii) the perception that these finer scale data will show that stock status in the local area is better than is reflected in coast-wide assessments. This approach can lead to more accurate allocation of local resources, provided that the spatial scales of interest for coastal communities match the scales of population-level processes that are naturally found within marine ecosystems (PMCC 2007). However, there is no reason to expect that natural population units will match the borders of local communities. If local management is implemented on too fine a scale, a single biological population could be subjected to independent and perhaps conflicting management regimes in different areas of its range.

Another factor that can limit use of genetic data in stock assessments is the trade-off between accuracy and precision. A typical stock assessment used for West Coast fish species has tens to hundreds of parameters. Dividing an area into multiple popula- tions should, all else being equal, reduce bias caused by assessing several populations as one. However, there will also be a cost in terms of reduced degrees of freedom and hence possibly lower precision when data from a single region are partitioned into several assessment areas. The trade-off can be examined using simulation (Punt 2003) or more generally using management strategy evaluation (MSE) (see below).

Finally, often it is not clear that modifying management advice to match biology 'matters' in the sense of affecting how fisheries management decisions will be made and implemented. For example, the recommendation to reduce fishing mortality for an overfished stock is likely to be robust to the choice of management units. A key role for assessment biologists is therefore to highlight the trade-offs and uncertainties (with respect to effects on management decisions) associated with different modelling and biological assumptions. In many cases, for example, uncertainties about reliability of abundance indices will dominate those related to stock structure.

\section{Allocation issues}

Allocation of access rights is one of the most important issues in fisheries management, and effective management generally requires a welldefined approach for allocation. Above we discussed how new genetic information can, for historical reasons, be difficult to accommodate into stock assessments. The same scenarios can create enormous challenges in deciding how management controls should be implemented in systems in which access rights have been allocated spatially. Individual transferable quotas (ITQs) have been used extensively worldwide and have formed the basis for fisheries management in Iceland and New Zealand since the 1980s. It is now common for total allowable catches (TACs) to be modified annually based on information from stock assessments. Consider a hypothetical species managed over a single region based on a TAC that is allocated in the form of ITQs. Suppose that new genetic evidence suggests that the region contains two demographically independent stocks. Ideally, this would lead to separate assessments for each stock and stock-specific TACs. However, this could raise a thorny allocation issue if the allocation rules do not explicitly account for this possibility. How should ITQs for the original (single) management unit be divided into ITQs for the newly defined units? 
Moreover, what should happen if one of the two stocks is assessed to be overfished while the other is not? Each ITQ holder currently has been allocated a percentage of the TAC, and one solution might be to give each ITQ holder that same percentage for each of the new stocks. However, this might mean that ITQ holders get new rights for areas they do not fish at the cost of rights for areas they do fish. Alternatively, if rights are allocated based on where individuals have fished historically, only fishers who harvest the overfished stock would have their rights reduced. Unfortunately, when a rights-based system is implemented, considerable attention is typically given to how access rights (including shares of TACs) are allocated, but potential consequences of subsequent changes in the definitions of the management units are almost never considered. This problem has occurred for blue warehou (Seriolella brama, Centrolophidae) off southern Australia. Genetic and other analyses suggest that separate stocks occur east and west of Bass Strait (Talman et al. 2003), and stock assessments are conducted by stock (Punt 2006a). However, TACs pertain to both stocks combined, and there has been no restriction on the fraction of the TAC taken from each stock.

\section{Organizational structure}

A clear need exists for geneticists to be more aware of standards applied by assessment scientists (and vice versa) and for both groups to be aware of the needs of managers. However, interchange of ideas to achieve this is often hampered by the organizational structure of management agencies, which frequently group scientists by discipline rather than by species. For example, a typical agency might have a genetics unit and a stock assessment unit, with only episodic communication between them. It is also uncommon for scientists other than those who conduct stock assessments to attend assessment and management meetings, and hence see how information on population structure feeds into the management process.

\section{An example - genetic stock identification of Chinook salmon}

Chinook salmon (Oncorhynchus tshawytscha, Salmonidae) is the largest Pacific salmon and is prized by sport, commercial and tribal fishers. Harvest primarily occurs at sea or in major rivers, where individuals from a few to over 100 populations can comingle. A brief review of the history of mixedstock fishery management for this species illustrates many of the complicating factors discussed above, as well as some novel ones.

\section{Background}

In the 1960s, development of the coded-wire tag (CWT: a small wire coded with alpha-numeric data that is inserted into the snout of juvenile fish) produced an effective means of tagging fish. Because the tags provide direct evidence of origin for individual fish, managers can use CWT data from samples of a fishery to shape the harvests (in space and time) to focus on abundant populations while keeping incidental take of at-risk stocks below acceptable levels. Valuable adaptive management information can also be obtained by differentially marking treatment groups within a hatchery. The CWT programme has been the cornerstone of salmon harvest management on the US West Coast for several decades and has been an integral part of international harvest management of Chinook salmon under the Pacific Salmon Treaty since the mid-1980s (Bernard and Clark 1996).

On the other hand, the CWT programme is expensive and labour intensive, as massive marking and recovery efforts must be conducted every year (Hammer and Blankenship 2001). Only a small fraction of fish is marked, so field workers have to either handle many fish to find the few with CWTs, or invest in expensive electronic wands to detect the tiny tags in the field. Because marking wild populations is difficult, virtually all available CWT information is for hatchery populations. Some tags are lost, and some errors occur in reading codes. Finally, with widespread population declines and associated harvest reductions, samples of marked fish are often too small to yield the desired precision.

Although the initial application of GSI was for sockeye salmon (Oncorhynchus nerka, Salmonidae, Grant et al. 1980), the first application on a coastwide scale occurred with Chinook salmon. A major advantage of GSI over the CWT is that GSI depends on naturally occurring genetic marks and thus can provide valuable insights into contributions by wild populations. Still, in spite of a number of demonstrated successes with Pacific salmon and other species, application of GSI to harvest management of Chinook salmon has been limited. Here are some of the reasons why this has occurred. 


\section{Biological and technical challenges}

Implementing GSI on a coast-wide (or Pacific Rim) scale requires extensive efforts to collect baseline data for populations from California to Alaska (or Asia) and to standardize laboratory procedures so that comparable data can be obtained by different state, federal and university laboratories (Shaklee et al. 1999; Seeb et al. 2007). This requires broad collaboration among laboratories and a willingness to share unpublished data for use in management provisions that are a stumbling block for some potential participants. For the most part, no centralized funding is available for coast-wide GSI; therefore, funds have to be pieced together from diverse sources, typically on a year-to-year basis.

Chinook salmon GSI has experienced the "marker wars' described above (see also Appendix 1). The transition from allozymes to microsatellites over the past decade required major groundbreaking efforts to standardize data collection (LaHood et al. 2002; Moran et al. 2006). Now, some favour another major shift to SNPs. While energetic discussions among geneticists on the markers of the future take place, managers are reluctant to commit major funds lest they end up backing a soon-to-be obsolete technology.

After decades of being accustomed to definitive information about origins of individual fish provided by CWTs, some managers find it difficult to accept probabilistic assignments based on genetic markers, even in cases where other aspects of experimental design and analytical methodology lead to greater accuracy and precision of overall stock composition estimates. Moreover, GSI cannot generally distinguish separate treatments or release groups within a population, as can be done with CWTs.

\section{Institutional issues}

The CWT programme for Chinook salmon has a long history that spans the entire careers of many scientists, and this promotes inertia and resistance to change. Because management rules and treaties (especially the Pacific Salmon Treaty) have been developed based on models that rely on CWT data, changes to the technology (GSI vs. CWT) would require completely revamping some management rules. However, major changes cannot be implemented unilaterally; even demonstrably imperfect methods can be perpetuated because they have survived hard-fought efforts to reach agreement among parties with disparate objectives and perspectives. In general, broad participation is essential in the development of any new methodology.

\section{Communication}

Geneticists have not always taken the time to fully understand the intricacies of the management process so that genetic information can be packaged in the most effective manner, and limitations of GSI have not always been portrayed accurately. For example, GSI proponents have sometimes failed to realize that computer simulations can lead to overly optimistic estimates of the power of GSI to resolve mixtures of specific salmon populations (see Anderson et al. 2008), which can erode credibility. Conversely, scientists and managers involved in the CWT programme have been slow to acknowledge and integrate into their assessment paradigm the many empirical demonstrations that GSI can provide valuable management information.

\section{Solutions: some strategies for improving the use of genetic data in fisheries management}

As the problems identified above have many causes, improvements must come from a variety of directions as well. Below we outline some measures that should help to more fully integrate genetic considerations into fishery management, beginning with perhaps the single most important area where progress can be made - communication.

\section{Communication}

Integration

Stock assessments, and hence the provision of management advice, are usually conducted by 'assessment teams' and peer-reviewed prior to being used for management (see boxes in Fig. 2 above the 'Wall of Science'). Historically, assessment teams have primarily included quantitative fishery biologists employed by fishery management agencies. In appropriate situations, the teams should be expanded to include geneticists as well as academics, statisticians and field biologists. This would improve understanding of the needs of managers, and it would also bring the latest technologies to the attention of those tasked with providing management advice. Adding geneticists to assessment teams would also help alleviate the perception that geneticists are 'ivory tower scientists' who seldom 
understand how their results can actually be used. However, geneticists are not the only group currently under-represented on assessment teams. For example, it is not uncommon for assessment teams not to include the field biologists who are most familiar with the bulk of the data sources used, and for managers (and other stakeholders) not to participate in meetings of assessment teams thereby potentially rendering the assessment process uninformative for management purposes.

Unfortunately, most geneticists (and field biologists) are not exposed to the techniques of statistical model fitting and decision analysis that form the basis for modern stock assessment science. Therefore, it might be necessary for management agencies (perhaps in collaboration with academic institutions) to develop courses to prepare geneticists (and others) for work on assessment teams. Such courses are now standard for decision makers in Australia and the USA. Conversely, most managers and assessment biologist alike would benefit from a greater literacy regarding the evolutionary forces (and associated methods) that can profoundly affect the living resources for which they share stewardship responsibility. For the past several years, the US Fish and Wildlife Service has offered a course in Applied Conservation Genetics to managers and biologists (information available at http://doilearn. doi.gov/CourseCatalog/index.cfm; accessed August 2008). Consistent with the agency's mission, this course typically emphasizes terrestrial and freshwater species. A comparable course that focused on issues of particular relevance to marine species could help bridge the information gap between geneticists, managers and stock assessment biologists.

\section{Improved dialogue}

Scientists, managers and policymakers could work together more effectively to foster productive dialogue about the relationship between statutory definitions and management or conservation goals. Just as terms like 'population' or 'stock' do not have unique biological definitions, most managementrelated problems do not have a single, generic scientific solution. Therefore, it is important to clearly articulate the goals one is trying to accomplish and how key terms are being used so that scientific evaluations can be conducted and communicated in the most effective way. For example, within the USA, the MSA states that 'To the extent practicable, an individual stock of fish shall be managed as a unit throughout its range, and interrelated stocks of fish shall be managed as a unit or in close coordination'. However, the MSA does not define what an 'individual stock' is, which leaves the term open to a wide range of interpretations. Similar issues apply to most other major pieces of legislation, such as the ESA and MMPA management agencies are legally mandated to use scientific methods to achieve societal goals, but doing so requires dealing with poorly defined legal terms that have no precise biological definitions. As discussed above, the idea that stocks are demographically independent units lies at the core of much of marine conservation and management. To maximize the usefulness of genetic information for fishery management, geneticists could do a better job in focusing on questions related to demographic independence rather than (or in addition to) more traditional analyses that provide insights into levels of gene flow. For reasons outlined above, this will be challenging; so, it is reasonable to expect that improvements will come only incrementally.

In general, units are demographically independent if population dynamics is affected more by local demographic processes (births and deaths) than by immigration or emigration. However, the appropriate threshold to use in determining demographic independence can differ depending on which processes one is primarily interested in. For example, the concept of demographic independence is central to three landmark US laws that guide management of living marine resources, but each piece of legislation implies a different flavour of demographic independence (Eagle et al. 2008):

1. The ESA is primarily concerned with extinction risk. It is difficult to conduct meaningful viability analyses on units that are not demographically independent; therefore, identifying such units should be a key step in status assessments and recovery planning. In one framework that has been adopted to guide recovery planning for ESAlisted Pacific salmon (McElhany et al. 2000), populations are considered demographically independent if the level of immigration from other populations is low enough that it does not appreciably affect extinction risk on a 100-year time frame.

2. Goals of the MMPA include maintaining marine mammal stocks as functioning elements of their ecosystems. In defining stocks, therefore, it is important to consider units that might suffer 
local depletion. It is easy to imagine that migration levels that can affect extinction probabilities over 100 years might be too small to have an appreciable effect in avoiding local depletions on ecological time frames.

3. Under the MSA, when a stock is considered overfished it triggers management actions that are projected to rebuild the stock within 10 years (with an adjustment to the recovery time if the stock cannot be rebuilt in 10 years). This implies a short time horizon; demographic linkages must be very strong for nearby populations to have an appreciable rescue effect within an MSA rebuild period.

These different flavours of demographic independence, each valid in its own context, mean that managers need to define in operational terms what they mean by 'demographic independence' or 'individual stock'. After management goals and operational concepts are clarified, it is the responsibility of scientists (including, but not limited to, geneticists) to develop analyses that will deliver information in the necessary format and currency. Although some common themes will emerge, these processes - both reviewing and articulating management goals and developing operational definitions for key terms will be unique for each specific application.

An innovative programme in coastal Oregon and California employs out-of-work fishers to conduct widespread sampling of the marine distribution of salmon (Bellinger et al. 2007). Under this programme, samples collected are genetically analysed by using GSI methods to provide a more complete picture of stock composition in space and time than is possible with current sampling regimes. This collaborative, multi-stakeholder project could help bridge long-standing gaps between geneticists, fishery biologists, managers and fishers and could serve as a model for how to facilitate understanding of genetic data and its integration into fishery management.

\section{Getting real}

Over the last 25 years, geneticists have sometimes oversold the products they can deliver. These examples of 'crying wolf' are remembered by decision makers and assessment scientists, and this has helped to erode confidence in advice provided by geneticists. Scientists, managers and living marine resources alike will be better served in the future if geneticists (and other scientists as well) make a concerted effort to understand the limitations as well as the power of the methods they use, and to understand appropriate (and inappropriate) applications in the management realm. Conversely, managers and fishery assessment biologists can 'get real' by showing more genuine interest in genetic and evolutionary processes and being receptive to the many geneticists who are capable of communicating complex topics to non-geneticists.

\section{Analytical methods}

Over the past decade, three factors have conspired to produce a veritable information explosion of genetic data: development of DNA technology that can identify large numbers of highly variable markers; development of sophisticated new statistical methods for analysing population genetic data; and continuing rapid increases in computational power (see Hauser and Seeb 2008). Some of the new analytical techniques, broadly known as assignment methods (Pearse and Crandall 2004; Manel et al. 2005), have the potential to study contemporary dispersal over ecological time frames, rather than relying on assumptions about long-term migration-drift equilibrium, as do most standard population genetic models. With careful application, these new methods should be able to provide information of management relevance. However, like the traditional methods, they are also constrained by biological and statistical realities. Power to detect migrants depends on genetic differences among populations, which are inversely related to levels of gene flow. Migrants can be most reliably detected in strongly diverged populations, but it is generally easy to show with traditional genetic methods that strongly diverged populations cannot be exchanging enough migrants to be demographically coupled. Conversely, when migrants are numerous, perhaps near the proportion required to produce demographic coupling, they will be genetically similar to resident individuals and thus difficult to detect using genetic markers (Paetkau et al. 2004; Manel et al. 2005). This limitation can be gradually eased with the use of more and more genetic markers, but the problem is likely to remain challenging for the foreseeable future.

Although the dominant paradigm in population genetic studies of natural populations still involves collecting individuals from two or more geographic locations and considering them putative populations, 
landscape genetics - the study of spatial genetic patterns in continuously distributed species - is rapidly evolving (Manel et al. 2003; Guillot et al. 2005). Most landscape genetic methods have been developed with terrestrial species in mind, but they are beginning to be applied to marine species as well (Palumbi 2003; Galindo et al. 2006; Selkoe et al. 2008). These studies provide important insights into biological processes and, for example, can help guide decisions about optimal design and efficacy of marine reserves. However, the population structures these models describe cannot be easily accommodated by conventional population assessments. Taking advantage of new insights that are possible from the field of landscape genetics will require considerable dialogue between geneticists, stock assessment scientists and managers, as well as creative thinking on both sides to develop effective ways to integrate these insights into stock assessment and management.

Finally, because the signal of population differentiation is often weak in marine species, it is important to take advantages of all types of information that shed light on population structure. Geneticists could do a better job of integrating their data with other types of biological and oceanographic information; see Selkoe et al. (2008) for a number of recent, encouraging examples showing how this can be performed. Ideally, this would involve collaborations at the experimental design stage so that joint sampling and analytical efforts can be planned more effectively. In particular, it is difficult to develop an ideal sampling design for a genetic study without understanding the details of the life history of the target species and physical processes in the marine realm.

\section{Institutional changes}

Institutional changes typically occur very slowly because considerable inertia must be overcome. For example, the problem of how to reallocate rights if our understanding of stock structure changes will probably require resolution in the courts for those species whose rights have already been allocated. However, the possibility that such changes will occur in the future should be recognized and the processes for reallocating rights should be included in any future management plans that include individual rights (such as systems based on ITQs or territorial rights). Similarly, although lack of appropriate historical information might currently limit the ability to separately manage some stocks (or even species) that are biologically distinct (see examples of black rockfish, blue rockfish and Acadian redfish cited above), we can begin now to collect the necessary information that in the future should reduce the discrepancy between biological units and management units. More generally, if serious efforts are made as outlined above to improve integration and dialogue, the institutional barriers to fuller use of genetic information in fishery management should be significantly weakened.

\section{Being opportunistic}

Historical factors have contributed to the lack of full integration of genetics into fishery management and still represent inertia that must be overcome. However, changes are possible under some circumstances, and geneticists and managers alike have to be ready to take advantages of opportunities as they arise. For example, in response to increasing logistical challenges to the coast-wide CWT programme (detailed above in the Example) and increasing awareness of the potential of GSI, the Pacific Salmon Commission sponsored two workshops in 2007 having the following objectives:

"To develop recommendations for integration of GSI information into a coordinated coast-wide management system to improve the ability of ocean fisheries to access abundant stocks within impact constraints established for other specific stocks and, to the extent possible, to identify and quantify the costs, implementation steps and timeframes to implement these recommendations".

Following these workshops, a set of recommendations was developed (Pacific Salmon Commission 2008) that provides at least a partial roadmap for better integration of genetics into West Coast salmon management.

\section{Emerging areas where genetic information can improve fisheries management}

\section{Management strategy evaluation}

The bulk of management actions designed to achieve the objectives of national legislation (e.g. ESA, MSA and MMPA in the USA) and multinational fisheries management agreements (e.g. IWC and ICES) affect fisheries either directly or indirectly. These actions include restrictions on inputs through closed areas and limitations on 
fishing effort, and on outputs through catch limits. For most resource management problems, the key uncertainties relate to how many populations exist and what their statuses are. Genetics has a role to play in informing both of these issues. Management strategies (sets of rules which specify the data on which management decisions are based and stipulate what management actions will be taken given what the data say about the status of the management system) have been developed in many jurisdictions. For example, management (or harvest) strategies have been adopted formally in South Africa for management of several of its most economically valuable fishery resources (Plagányi et al. 2007) and by the IWC for management of commercial and aboriginal whaling (Punt and Donovan 2007). In most jurisdictions that have not formally adopted management strategies, management decisions are nevertheless based in some way on decision rules which approximate fully specified management strategies (Smith et al. in press).

Management decision making, whether based on formal management strategies or not, depend on a variety of assumptions, some related to population dynamics and others to stock structure. It is important to determine which assumptions, if violated, will most seriously compromise the ability to achieve management objectives. This process, often referred to as Management Strategy Evaluation (MSE; Smith 1994), involves developing a number of alternative models (operating models) to capture plausible alternative hypotheses regarding the dynamics of the system to be managed, and then evaluating the management consequences or outcomes (summarized by the resulting status of managed stocks and of catches and other measures of management success) for each alternative hypothesis.

Management strategy evaluation has been described extensively elsewhere (Smith 1994; Butterworth et al. 1997; Punt 2006b). A key aspect of MSE for our purposes is to select an appropriate range of plausible stock structure hypotheses, because it is well known that performance of a management strategy can be poor in the face of this source of uncertainty (IWC 1992, 1993). Genetics (and other approaches to identifying stock structure) can be important in selecting and refining such hypotheses. For example, the IWC SC recently evaluated management strategies for Western North Pacific minke whales (Balaenoptera acutoro- strata, Balaenopteridae) (IWC, 2004), motivated in part by the need to consider the implications of harvest during migration. Three major stock-structure hypotheses were considered: (i) two stocks (west and east of Japan); (ii) three stocks (one west and two east of Japan) and (iii) four stocks (one west and three east of Japan) (Fig. 3). The least complicated stock-structure hypotheses (two and three stocks; Fig. 3 upper two panels) were justified primarily by the lack of evidence for multiple populations from statistical hypothesis tests applied to a range of genetic and non-genetic data. The most complicated hypothesis (four stocks; Fig. 3 bottom panel) arose from the application of a clustering algorithm (Martien and Taylor 2001) to mtDNA data. Perhaps not unexpectedly, the operating models based on four stocks posed more of a challenge to the candidate management strategies, and uncertainty about stock structure led, in part, to the IWC SC being unable to reach agreement on relative weights for different stock structure hypotheses.

Thus, even when it is not possible to fully integrate genetic data into fishery management models, genetic information can be used through the MSE process to help assess the consequences of ignoring population structure. Only a limited examination of the implications of failure to correctly identify stock structure has been conducted to date (Punt 2006b, 2008), but this could be expanded considerably. This would help managers assess the consequences of incomplete information or situations where it proves impossible to formally integrate genetic information into management advice.

\section{Novel applications}

This paper has focused on two major themes (stock identification and mixed-stock fishery analysis), as these are among the most pressing management problems and the ones for which use of genetic information is most common. However, genetic data can potentially provide valuable insights into a number of other questions of direct management relevance. These include the following.

\section{Population abundance}

The two most important outcomes from any stock assessment are current status (the current population size $(N)$ and the population size relative to management reference points) and productivity. Several genetic approaches can provide information 

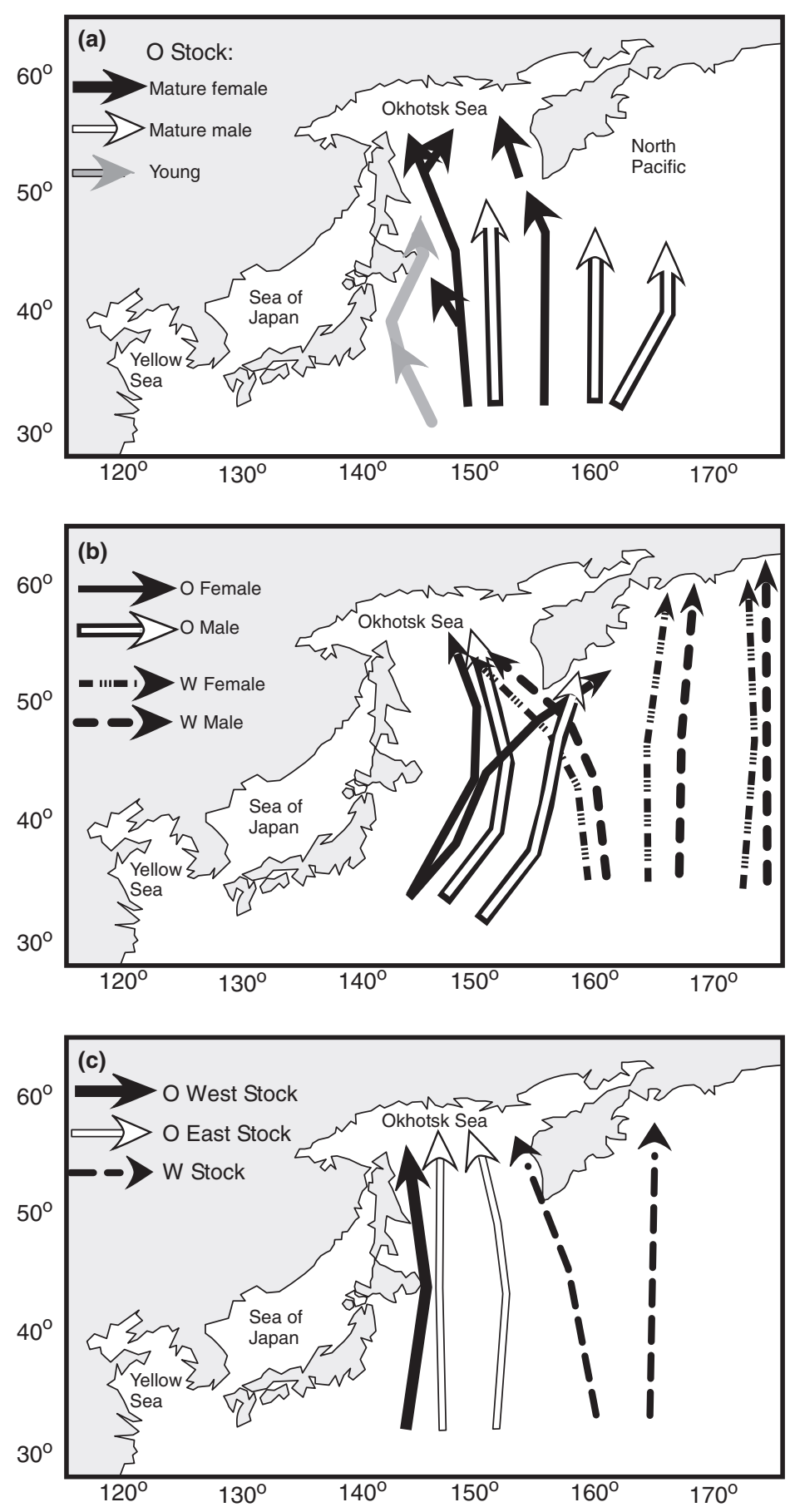

Figure 3 Summary of three major stock structure hypotheses (a, b, c) examined by the IWC SC during its evaluation of management strategies for the Western North Pacific minke whales. Arrows show putative migration routes between breeding and feeding grounds. The stock structure hypotheses arise from different ways of interpreting genetic and non-genetic information. In each panel, another stock (J, not shown) occurs to the West of Japan; each hypothesis also includes minor variants not shown here. Adapted from IWC (2004), with thanks to Greg Donovan and Kathleen Neely. about population abundance. The widely used mark-recapture method can be implemented effectively using multilocus genotypes as unique genetic marks. For terrestrial species, abundance estimates can be based on non-invasive sampling of scat, hair or feather samples (reviewed by Schwartz et al. 2007). Marine species present some special chal- lenges, but this approach can be feasible if population size is not too large (Palsbøll et al. 1997). Highly polymorphic markers can produce unique multilocus genotypes for each individual, so these methods can be used not only to estimate $\mathrm{N}$ but also to track movement of individuals in space and time. Australian scientists have developed a special hook 
that can take small biopsies for DNA marking (Buckworth et al. 2008), and a variant of this approach has been used to study abundance and distribution of rockfish (Sebastes spp.) within a conservation area in the Pacific Northwest (Hague 2006).

Although census size is generally of primary interest to managers, effective population size is of considerable evolutionary and conservation relevance and can be estimated using genetic markers (Schwartz et al. 1998; Leberg 2005). Furthermore, if the ratio $N_{\mathrm{e}} / N$ is known or can be estimated (see Hauser and Carvalho 2008), a genetically based estimate of $N_{\mathrm{e}}$ can provide a rough indication of $N$ (Laurent and Planes 2007). A single-sample estimator of $N_{\mathrm{e}}$ based on linkage disequilibrium (Hill 1981) has seen relatively few practical applications, but has considerable potential to provide useful information about contemporary $N_{\mathrm{e}}$ (Waples and Do 2008). A novel application of a related method used current diversity of mtDNA to estimate the minimum (bottleneck) population size of cetaceans at the time commercial whaling was suspended (Jackson et al. 2008). Minimum bounds on population size obtained in this way have been included in recent cetacean stock assessments in the southern hemisphere. Assessments without the bound tend to indicate that humpback whale stocks were reduced to very low levels (below the minima implied by the genetic bounds) and have faster recovery rates (Johnson et al. in press). Other genetically based methods for estimating $N$ in marine species include kinship analysis (Skaug 2001) and paternity analysis (Nielsen et al. 2001). Parentage analysis can also be used to study mating systems and patterns of realized reproductive success (Bekkevold et al. 2002) in marine species.

\section{A global testing of genetic techniques for management purposes}

Difficulties in using genetic data in stock assessments are compounded by the plethora of genetic methods, most of which have not been tested within a management context. To address this problem, the IWC SC has sponsored a global effort (testing of spatial structure models; IWC 2007b) to compare the performance of different genetic methods on common data sets. Importantly, performance is evaluated not only in terms of correctly identifying the 'true' number of populations, but also with respect to achieving management goals of sustainable utilization.

\section{Miscellaneous}

Other potential genetically based methods, all with empirical demonstrations of applicability to aquatic species, are too numerous to treat in detail here. These include analysis of fishery bycatch (Baker et al. 2006), identification of early life stages (Graves et al. 1990), forensic analysis of species at risk and product labelling (Schwenke et al. 2006, Ogden 2008), identifying origins of invasive species (Audzijonyte et al. 2008; Hess et al. in press), studying maturation and reproductive potential (Swanson et al. 2008), population genomics (Goetz and MacKenzie 2008), the link between the genotype and the phenotype (Naish and Hard 2008) and analysis of historical DNA samples to provide a temporal perspective on population genetic structure (Nielsen and Hansen 2008).

\section{Conclusions}

Numerous factors have contributed to the imperfect integration of genetic data into management of marine species. Some factors are inherently biological and relate to the relatively low signal-to-noise ratio for population structure in many marine species. Increasingly powerful laboratory and analytical techniques will make incremental progress in reducing these limitations. Considerable room for improvement exists on many communication issues involving geneticists, fishery biologists and managers. Historical factors that are largely out of the control of geneticists also impede integration of genetic information, and progress in these areas is likely to be episodic and opportunistic. However, even when historical factors impede full integration, genetic data can still be used to help assess the likely consequences of ignoring particular types of population structure, and this information can be valuable in the interim and, potentially, help the transition to a more effective management framework.

Consistent with the theme of this special issue, our paper has focused on the use of genetic information in fishery management. Some of the issues discussed above (especially those dealing with communication) are particularly challenging for geneticists because fishery stock assessments and fishery management are based primarily on ecological rather than evolutionary principles. These two fields of study are still imperfectly integrated, even in academic institutions where they are housed in the same department. Other 
challenges to better integration of genetic data (e.g. the need to produce timely information of management relevance in a currency that is useful to decision makers; difficulties associated with replacing outdated but accepted methods with promising new technologies; the importance of providing realistic assessments of both the power and limitations of each method, as well as associated uncertainties and the consequences of making different types of errors) are simply new twists on themes that have long affected the use of science in fishery management (Francis and Shotton 1997; Dayton 1998). In a broader sense, the topics discussed here reflect parallel issues about the appropriate relationship between science, management and environmental policy (Meffe et al. 1998). Although this relationship has a troubled history (Houck 2003), clear opportunities exist for science to better inform fishery management, and better integration of genetic data can help advance that enterprise.

\section{Acknowledgments}

We thank Terry Beacham, Michael Hansen, Robert Kope and Paul Moran for valuable discussions and information. Elizabeth Clarke, Bob Francis, Jann Martinsohn, Kevin Stokes, the associate editor (Lorenz Hauser) and an anonymous reviewer provided useful comments on an earlier version of this paper. We are indebted to Fred Utter for the Appendix.

\section{References}

Anderson, E.C., Waples, R.S. and Kalinowski, S.T. (2008) An improved method for predicting the accuracy of genetic stock identification. Canadian Journal of Fisheries and Aquatic Sciences, 65, 1475-1486.

Andrewartha, H.G. and Birch, L.C. (1984) The Ecological Web. University of Chicago Press, Chicago, IL.

Audzijonyte, A., Wittmann, K.J. and Vainola, R. (2008) Tracing recent invasions of the Ponto-Caspian mysid shrimp Hemimysis anomala across Europe and to North America with mitochondrial DNA. Diversity and Distributions 14, 179-186.

Backman, T.W.H. and Berg, L. (1992) Managing molecules or saving salmon? The evolutionary significant unit. Wana Chinook Tymoo (Columbia River Inter-Tribal Fish Commission) 2, 8-14.

Baker, B.M. (1999) Genetic analysis of eight black rockfish collections from northern Oregon. Unpublished report, Washington Department of Fish and Wildlife, Olympia, WA, 27 pp.
Baker, C.S., Lukoschek, V., Lavery, S., Dalebout, M.L., Yong-Un, M., Endo, T. and Funahashi, N. (2006) Incomplete reporting of whale, dolphin and porpoise 'bycatch' revealed by molecular monitoring of Korean markets. Animal Conservation 9, 474-482.

Beacham, T.D., Pollard, S. and Le, K.D. (1999) Population structure and stock identification of steelhead in southern British Columbia, Washington, and the Columbia River based on microsatellite DNA variation. Transactions of the American Fisheries Society 128, 1068-1084.

Beacham, T.D., Lapointe, M., Candy, J.R., Miller, K.M. and Withler, R.E. (2004) DNA in action: rapid application of DNA variation to sockeye salmon fisheries management. Conservation Genetics 5, 411-416.

Bekkevold, D., Hansen, M.M. and Loeschcke, V. (2002) Male reproductive competition in spawning aggregations of cod (Gadus morhua, L.). Molecular Ecology 11, 91-102.

Bellinger, R., Lawson, P., Sylvia, G. et al. (2007) Project CROOS: collaborative research on Oregon ocean salmon. Final Report to the Oregon Salmon Commission. Oregon State University, Corvallis, OR.

Bernard, D.R. and Clark, J.E. (1996) Estimating salmon harvest with coded-wire tags. Canadian Journal of Fisheries and Aquatic Sciences 53, 2323-2332.

Brown, B.L., Epifanio, J.M., Smouse, P.E. and Kobak, C.J. (1996) Temporal stability of mtDNA haplotype frequencies in American shad stocks: to pool or not to pool across years? Canadian Journal of Fisheries and Aquatic Sciences 53, 2274-2283.

Buckworth, R.C., Ovenden, J.R., Broderick, D. and Macbeth, M. (2008) Proof of concept for 'Genetag': genetic tagging for monitoring mortality rates and catchability (Advances in Fish Tagging and Marking Technology: An International Symposium. Auckland, NZ, February 2008), Abstract available at: http://www.fisheries.org/ units/tag2008/FishTagging_abstracts.pdf.

Burford, M.O. and Bernardi, G. (2008) Incipient speciation within a subgenus of rockfish (Sebastomus) provides evidence of recent radiations within an ancient species flock. Marine Biology 154, 701-717.

Burford, M.O. and Larson, R.J. (2007) Genetic heterogeneity in a single year-class from a panmictic population of adult blue rockfish (Sebastes mystinus). Marine Biology 151, 451-465.

Butterworth, D.S., Cochrane, K.L. and De Oliveira, J.A.A. (1997) Management procedures: a better way to manage fisheries? The South African experience. American Fisheries Society Symposium 20, 83-90.

Cadrin, S.X., Friedland, K.D. and Waldman, J.R. (eds) (2005) Stock Identification Methods: Applications to Fishery Science. Elsevier Academic Press, Amsterdam.

Clark, A.G., Hubisz, M.J., Bustamonte, C.D., Williamson, S.H. and Nielsen, R. (2005) Ascertainment bias in studies of genome-wide polymorphism. Genome Research 15, 1496-1502. 
Constable, H. (2006) Population Genetics of Juvenile Sebastes jordani, Shortbelly Rockfish, along the California Coast. Masters Thesis, Department of Biology, San Francisco State University, San Francisco, CA.

Cope, J.M. (2004) Population genetics and phylogeography of the blue rockfish (Sebastes mystinus) from Washington to California. Canadian Journal of Fisheries and Aquatic Sciences 61, 332-342.

Cope, J.M. and MacCall, A.D. (2005) Status of Kelp Greenling (Hexagrammos decagrammus) in Oregon and California Waters as Assessed in 2005. Pacific Fishery Management Council, Portland, OR, 158 pp.

Cope, J.M. and Punt, A.E. (2005) Status of Cabezon (Scorpaenichthys marmoratus) in California Waters as Assessed in 2005. Pacific Fishery Management Council, Portland, OR, 190 pp.

Cope, J.M., Piner, K.R., Minte-Vera, C.V. and Punt, A.E. (2004) Status and Future Prospects for the Cabezon (Scorpaneichthys marmoratus) as Assessed in 2003. Pacific Fishery Management Council, Portland, OR, 147 pp.

Corander, J., Waldmann, P., Marttinen, P. and Sillanpaa, M.J. (2004) BAPS2: enhanced possibilities for the analysis of genetic population structure. Bioinformatics 20, 2363-2369.

Crandall, K.A., Bininda-Emonds, O.R.P., Mace, G.M. and Wayne, R.K. (2000) Considering evolutionary processes in conservation biology. Trends in Ecology and Evolution 15, 290-295.

Cronin, M.A. (2007) EIEIO: old MacDonald would have known how to fix the Endangered Species Act. Range Magazine, Spring 2007, 24-25.

Dayton, P. (1998) Reversal of the burden of proof in fishery management. Science 279, 821-822.

Dick, E.J., Ralston, S. and Pearson, D. (2007) Status of Cowcod, Sebastes levis, in the Southern California Bight. Pacific Fishery Management Council, Portland, OR, 90 pp.

Eagle, T.C., Cadrin, S.X., Caldwell, M.E., Methot, R.D. and Nammack, M.F. (eds) (2008) Conservation Units of Managed Fish, Threatened or Endangered Species, and Marine Mammals: Report of a Workshop: 14-16 February 2006, Silver Spring, MD. NOAA Technical Memorandum NMFS-OPR-37.

Fay, G. (2005) Stock Assessment and Status of Longspine Thornyhead (Sebatolobus altivelis) off California, Oregon and Washington in 2005. Pacific Fishery Management Council, Portland, OR, 98 pp.

Field, J.C. (2007) Status of the Chilipepper Rockfish, Sebastes goodei, in 2007. Pacific Fishery Management Council, Portland, OR, $227 \mathrm{pp}$.

Field, J.C., Punt, A.E., Methot, R.D. and Thomson, C.J. (2006) Does MPA mean "Major Problem for Assessments?" Considering the consequences of placebased management systems. Fish and Fisheries 7, 284302.
Field, J.C., Dick, E.J. and MacCall, A.D. (2007) Stock Assessment Model for the Shortbelly Rockfish, Sebastes jordani, in the California Current. Pacific Fishery Management Council, Portland, OR, 108 pp.

Francis, R.I.C.C. (2006). Assessment of Hoki (Macruronus novaezelandiae) in 2005. New Zealand Fisheries Assessment Report 2006/3. Available from the NIWA library, Wellington.

Francis, R.I.C.C. and Shotton, R. (1997) 'Risk' in fisheries management: a review. Canadian Journal of Fisheries and Aquatic Sciences 54, 1699-1715.

Frankham, R., Ballou, J.D. and Bricoe, D.A. (2002) Introduction to Conservation Genetics. Cambridge University Press, Cambridge, UK.

Galindo, H.M., Olson, D.B. and Palumbi, S.R. (2006) Seascape genetics: a coupled oceanographic-genetic model predicts population structure of Caribbean corals. Current Biology 16, 1622-1626.

Gauldie, R.W. (1991) Taking stock of genetic concepts in fisheries management. Canadian Journal of Fisheries and Aquatic Sciences 48, 722-731.

Gertseva, V.V. and Schirripa, M.J. (2007) Status of the Longnose Skate (Raja rhina) off the Continental US Pacific Coast in 2007. Pacific Fishery Management Council, Portland, OR, 132 pp.

Goetz, F. and MacKenzie, S. (2008) Functional genomics in fish biology and fisheries. Fish and Fisheries 9, 378-395.

Gomez-Uchida, D. and Banks, M.A. (2005) Microsatellite analyses of spatial genetic structure in darkblotched rockfish (Sebastes crameri): Is pooling samples safe? Canadian Journal of Fisheries and Aquatic Sciences 62, 1874-1886.

Grant, W.S., Milner, G.B., Krasnowski, P. et al. (1980) Use of biochemical genetic variants for identification of sockeye salmon (Oncorhynchus nerka) stocks in Cook Inlet, Alaska. Canadian Journal of Fisheries and Aquatic Sciences 37, 1236-1247.

Graves, J.E., Curtis, M.J., Oeth, P.A. and Waples, R.S. (1990) Biochemical genetics of southern California basses of the genus Paralabrax and a method for the specific identification of fresh and ethanol-preserved individual eggs and early larvae. Fishery Bulletin (U.S.) 88, 59-66.

Guillot, G., Estoup, A., Mortier, F. and Cosson, J.F. (2005) A spatial statistical model for landscape genetics. Genetics 170, 1261-1280.

Haddon, M. (2001) Modelling and Quantitative Methods in Fisheries. Chapman \& Hall/CRC, New York.

Hague, M.J. (2006) The Use of Genetic Tagging to Assess Inshore Rockfish Populations within a Marine Conservation Area in the Strait of Georgia. MS Thesis, Simon Fraser University, Vancouver, BC.

Hamel, O.S. (2005a) Status and Future Prospects for the Pacific Ocean Perch Resource in Waters off Washington and Oregon as Assessed in 2005. Pacific Fishery Management Council, Portland, OR, 76 pp. 
Hamel, O.S. (2005b) Status and Future Prospects for the Shortspine Thornyhead Resource in Waters off Washington, Oregon, and California as Assessed in 2005. Pacific Fishery Management Council, Portland, OR, 74 pp.

Hamel, O.S. (2007) Status and Future Prospects for the Darkblotched Rockfish Resources in Waters off Washington, Oregon, and California as assessed in 2007. Pacific Fishery Management Council, Portland, OR, $179 \mathrm{pp}$.

Hammer, S.A. and Blankenship, H.L. (2001) Technical notes: cost comparison of marks, tags, and mark-withtag combinations used in salmonid research. North American Journal of Aquaculture 63, 171-178.

Hastings, A. (1993) Complex interactions between dispersal and dynamics: lessons from coupled logistic equations. Ecology 74, 1362-1372.

Hauser, L. and Carvalho, G.R. (2008) Paradigm shifts in fisheries genetics: ugly hypotheses slain by beautiful facts. Fish and Fisheries 9, 333-362.

Hauser, L. and Seeb, J.E. (2008) Advances in molecular technology and their impact on fisheries genetics. Fish and Fisheries 9, 473-486.

Hauser, L., Seamons, T.R., Dauer, M., Naish, K.A. and Quinn, T.P. (2006) An empirical verification of population assignment methods by marking and parentage data: hatchery and wild steelhead (Oncorhynchus mykiss) in Forks Creek, Washington, USA. Molecular Ecology 15 , 3157-3173.

He, X., Pearson, D.E., Dick, E.J., Field, J.F., Ralston, S. and MacCall, A.D. (2005) Status of the Widow Rockfish Resource in 2005. Pacific Fishery Management Council, Portland, OR, $119 \mathrm{pp}$.

Hebert, P.D.N., Stoeckle, M.Y., Zemlak, T.S. and Francis, C.M. (2004) Identification of birds through DNA barcodes. PLoS Biology 2, 1657-1663.

Hedgecock, D., Barber, P.H. and Edmands, S. (2007) Genetic approaches to measuring connectivity. Oceanography 20, 70-79.

Helser, T.E. (2005) Stock Assessment of the Blackgill Rockfish (Sebastes melanostomus) Population off the West Coast of the United States in 2005. Pacific Fishery Management Council, Portland, OR, 117 pp.

Helser, T.E. and Martell, S.J. (2007) Stock Assessment of Pacific Hake (whiting) in U.S. and Canadian Waters in 2007. Pacific Fishery Management Council, Portland, OR, $225 \mathrm{pp}$.

Hess, J.E., Swalla, B.J. and Moran, P. (in press) New molecular markers to genetically differentiate populations of Didemnum vexillum (Kott, 2002) - an invasive ascidian species. Aquatic Invasions.

Hilborn, R. and Walters, C.J. (1992) Quantitative Fisheries Stock Assessment: Choice, Dynamics and Uncertainty. Chapman \& Hall, New York.

Hill, W.G. (1981) Estimation of effective population size from data on linkage disequilibrium. Genetical Research (Cambridge) 38, 209-216.
Horn, P.L. and Sullivan, K.J. (1996) Validated aging methodology using otoliths, and growth parameters for hoki (Macruronus novaezelandiae) in New Zealand waters. New Zealand Journal of Marine and Freshwater Research 30, 161-174.

Houck, O. (2003) Tales from a troubled marriage: science and law in environmental policy. Science 302, 1926 1929.

Hurst, R.J., Bagley, N.W., McGregor, G.A. and Francis, P. (1999) Movement of the New Zealand school shark, Galeorhinus galeus, from tag returns. New Zealand Journal of Marine and Freshwater Research 33, 29-48.

Hyde, J.R., Kimbrell, C.A., Budrick, J.E., Lynn, E.A. and Vetter, R.D. (2008) Cryptic speciation in the vermilion rockfish (Sebastes miniatus) and the role of bathymetry in the speciation process. Molecular Ecology 17, 1122-1136.

Iwamoto, E., Ford, M.J. and Gustafson, R.G. (2004) Genetic population structure of Pacific hake, Merluccius productus, in the Pacific Northwest. Environmental Biology of Fishes 69, 187-199.

IWC. (1992) Report of the Scientific Committee, Annex D. Report of the Sub-Committee on Management Procedures. Reports of the International Whaling Commission 42, 87-136.

IWC. (1993) Report of the Scientific Committee, Annex I. Report of the Working Group on Implementation Trials. Reports of the International Whaling Commission 43, 153196.

IWC. (2004) Report of the Scientific Committee, Annex D. Report of the Sub-Committee on Management Procedures. Journal of Cetacean Research and Management 6(Suppl.), 75-184.

IWC. (2007a) Report of the Scientific Committee, Annex F. Report of the Sub-Committee on Bowhead, Right, and Gray Whales. Journal of Cetacean Research and Management 9(Suppl.), 142-155.

IWC. (2007b) Report of the 2nd TOSSOM (Testing of Spatial Structure Models) Workshop. Journal of Cetacean Research and Management 9(Suppl.), 489-498.

Jackson, J.A., Patenaude, N.J., Carroll, E.L. and Baker, C.S. (2008) How few whales were there after whaling? Inference from contemporary mtDNA diversity. Molecular Ecology 17, 236-251.

Jagielo, T.H. and Wallace, F.R. (2005) Assessment of Lingcod (Ophiodon elongatus) for the Pacific Fishery Management Council in 2005. Pacific Fishery Management Council, Portland, OR, 153 pp.

Jagielo, T.H., LeClair, L.L. and Vorderstrasse, B.A. (1996) Genetic variation and population structure of lingcod. Transactions of the American Fisheries Society 125, 372386.

Johnson, S.J., Zerbini, A. and Butterworth, D.S. (in press) A Bayesian approach to assess the status of Southern Hemisphere humpback whales (Megaptera novaengliae) with an application to breeding stock G. Journal of Cetacean Research and Management. 
Kaplan, I.C. and Helser, T.E. (2007) Stock Assessment of the Arrowtooth Flounder (Atheresthes stomias) Population off the West Coast of the United States in 2007. Pacific Fishery Management Council, Portland, OR, 233 pp.

Key, M., MacCall, A.D., Bishop, T. and Leos, B. (2005) Stock Assessment of the Gopher Rockfish. Pacific Fishery Management Council, Portland, OR, 58 pp.

Key, M.K., MacCall, A.D., Field, J., Aseltine-Nielson, D. and Lynn, K. (2008) The 2007 Assessment of Blue Rockfish (Sebastes mystinus) in California. Pacific Fishery Management Council, Portland, OR, 155 pp.

Koljonen, M.-L., Pella, J.J. and Masuda, M. (2005) Classical individual assignment versus mixture modelling to estimate stock proportions in Atlantic salmon (Salmo salar) catches from DNA microsatellite data. Canadian Journal of Fisheries and Aquatic Sciences 62, 2143-2158.

LaHood, E., Moran, P., Olsen, J., Grant, W.S. and Park, L.K. (2002) Microsatellite allele ladders in two species of Pacific salmon: preparation and field-test results. Molecular Ecology Notes, 2, 187-190.

Lai, H.-L., Haltuch, M.A., Punt, A.E. and Cope, J.M. (2005) Stock Assessment of Petrale Sole: 2004. Pacific Fishery Management Council, Portland, OR, 211 pp.

Latch, E.K., Dharmarajan, G., Glaubitz, J.C. and Rhodes, O.E. Jr (2006) Relative performance of Bayesian clustering software for inferring population substructure and individual assignment at low levels of population differentiation. Conservation Genetics 7, 295-302.

Laurent, V. and Planes, S. (2007) Effective population size estimation on Sardina pilchardus in the Bay of Biscay using a temporal genetic approach. Biological Journal of the Linnean Society 90, 591-602.

Leberg, P. (2005) Genetic approaches for estimating the effective size of populations. Journal of Wildlife Management 69, 1385-1399.

Livingston, M.E. and Schofield, K.A. (1996) Stock discrimination of hoki (Macruronus novaezelandiae Merlucciidae) in New Zealand waters, using morphometrics. New Zealand Journal of Marine and Freshwater Research 30, 197-208.

Livingston, M.E., Schofield, K.A. and Sullivan, K.J. (1992) The discrimination of hoki groups in New Zealand waters using morphometrics and age-growth parameters. New Zealand Fisheries Assessment Research Document 92/18. Available from the NIWA library, Wellington.

MacCall, A.D. (2005) Assessment of Vermilion Rockfish in Southern and Northern California. Pacific Fishery Management Council, Portland, OR, 128 pp.

Manel, S., Schwartz, M., Luikart, G. and Taberlet, P. (2003) Landscape genetics: combining landscape ecology and population genetics. Trends in Ecology and Evolution 18, 189-197.

Manel, S., Gaggiotti, O. and Waples, R.S. (2005) Assignment methods: matching biological questions with appropriate techniques. Trends in Ecology and Evolution 20, 136-142.
Martien, K.K. and Taylor, B.L. (2001) A new method of generating hypothesized population structures for continuously distributed species using genetic data. Paper SC/ 53SD7 presented to the IWC Scientific Committee, July 2001. Available from the Journal of Cetacean Research and Management, Cambridge, UK.

Martien, K. and Taylor, B.L. (2003) Limitations of hypothesis testing in defining management units for continuously distributed species. Journal of Cetacean Research and Management 5, 213-219.

Matala, A.P., Gray, A.K. and Gharrett, A.J. (2004) Microsatellite variation indicates population genetics structure of bocaccio. North American Journal of Fisheries Management 24, 1189-1202.

Maunder, M.N., Barnes, J.T., Aseltine-Nielson, D. and MacCall, A.D. (2005) The Status of California Scorpionfish (Scorpaena guttata) off Southern California in 2004. Pacific Fisheries Management Council, Portland, OR, 132 pp.

McElhany, P., Ruckelshaus, M.H., Ford, M.J., Wainwright, T.C. and Bjorkstedt, E.P. (2000) Viable Salmonid Populations and the Recovery of Evolutionarily Significant Units. NOAA Technical Memorandum NMFS-NWFSC 42, 156 pp.

McGauley, K. and Mulligan, T.J. (1995) Polymerase chain reaction-restriction fragment length polymorphism analysis of mitochondrial rRNA genes from yellowtail rockfish. Journal of Fish Biology 47, 744-747.

Meffe, G.K., Boersma, P.D., Murphy, D.D. et al. (1998) Independent scientific review in natural resource management. Conservation Biology 12, 268-270.

Methot, R. (1992) Assessment of the West Coast Sablefish Stock in 1992. Pacific Fishery Management Council, Portland, OR, 96 pp.

Methot, R.D. and Hightower, J. (1990) Assessment of the West Coast Sablefish Stock in 1990 and Recommendations to Management in 1991. Pacific Fishery Management Council, Portland, OR, 67 pp.

Miller, J.A., Banks, M.A., Gomez-Uchida, D. and Shanks, A.L. (2005) A comparison of population structure in black rockfish (Sebastes melanops) as determined with otolith microchemistry and microsatellite DNA. Canadian Journal of Fisheries and Aquatic Sciences 62, 21892198.

Milner, G.B., Teel, D.J., Utter, F.M. and Winans, G.A. (1985) A genetic method of stock identification in mixed populations of pacific salmon, Oncorhynchus spp. Marine Fisheries Review 47, 1-8.

Moran, P., Teel, D.J., LaHood, E., Drake, J. and Kalinowski, S.T. (2006) Standardizing multi-laboratory microsatellite data in Pacific salmon: an historical view of the future. Ecology of Freshwater Fish 15 , 597-605.

Morin, P.A., Luikart, G. and Wayne, R.K. and the SNP Working Group (2004a) SNPs in ecology, evolution and conservation. Trends in Ecology and Evolution 19, 208216. 
Morin, B., Methot, R., Sevigny, J.-M., Power, D., Branton, B. and Mcintyre, T. (2004b) Revue de la structure, de l'abondance et de la répartition de Sebastes mentella et S. fasciatus dans le Canada atlantique dans le contexte des espèces en péril [Review of the structure, the abundance and distribution of Sebastes mentella and S. fasciatus in Atlantic Canada in a species-at-risk context]. DFO, Canadian Science Advisory Secretariat, Research Document, 2004/058, 96 pp.

Moritz, C. (1994) Defining 'evolutionarily significant units' for conservation. Trends in Ecology and Evolution 9, 373375.

Naish, K. and Hard, J.J. (2008) Bridging the gap between the genotype and the phenotype: linking genetic variation, selection and adaptation in fishes. Fish and Fisheries 9, 396-422.

Narum, S.R., Buonaccorsi, V.P., Kimbrell, C.A. and Vetter, R.D. (2004) Genetic divergence between gopher rockfish (Sebastes carnatus) and black and yellow rockfish (Sebastes chrysomelas). Copeia 2004, 926-931.

Nielsen, E. and Hansen, M. (2008) Waking the dead: the value of genetic analyses of historical samples. Fish and Fisheries 9, 450-461.

Nielsen, R., Mattila, D.K., Clapham, P.J. and Palsbøll, P.J. (2001) Statistical approaches to paternity analysis in natural populations and applications to the North Atlantic humpback whale. Genetics 157, 1673-1682.

Ogden, R. (2008) Fisheries forensics: the use of DNA tools for improving compliance, traceability and enforcement in the fishing industry. Fish and Fisheries 9, 462-472.

Pacific Salmon Commission. (2008) Recommendations for application of Genetic Stock Identification (GSI) methods to management of ocean salmon fisheries: special report of the Genetic Stock Identification Steering Committee and the Pacific Salmon Commission's Committee on Scientific Cooperation. Pacific Salmon Communications Technical Report No. 23, 35 pp.

Paetkau, D., Slade, R., Burden, M. and Estoup, A. (2004) Genetic assignment methods for the direct, real-time estimation of migration rate: a simulation-based exploration of accuracy and power. Molecular Ecology 13, 5565.

Palsbøll, P., Allen, J., Bérubé, M. et al. (1997) Genetic tagging of humpback whales. Nature 388, 767-769.

Palumbi, S.R. (2003) Population genetics, demographic connectivity, and the design of marine reserves. Ecological Applications 13, S146-S158.

Pearse, D.E. and Crandall, K. (2004) Beyond $F_{\mathrm{ST}}$ : analysis of population genetic data for conservation. Conservation Genetics 5, 585-602.

Pearson, D.E. (1994) An initial examination of the status of the bank rockfish fishery off the coast of California. Southwest Fisheries Science Center, Santa Cruz, CA, 22 pp.

Pella, J. and Masuda, M. (2001) Bayesian methods for analysis of stock mixtures from genetic characters. Fishery Bulletin 99, 151-167.
Pella, J. and Masuda, M. (2006) The Gibbs and split-merge sampler for population mixture analysis from genetic data with incomplete baselines. Canadian Journal of Fisheries and Aquatic Sciences 63, 576-596.

Pella, J.J. and Milner, G.B. (1987) Use of genetic marks in stock composition analysis. In: Population Genetics \& Fishery Management (eds N. Ryman and F. Utter). University of Washington Press, Seattle, WA, pp. 247276.

Piner, K., Schirripa, M., Builder, T., Rogers, J. and Methot, R. (2000) Bank Rockfish (Sebastes rufus) Stock Assessment for Eureka, Monterey, and Conception INPFC Areas North of Pt. Conception, California. Pacific Fishery Management Council, Portland, OR, 65 pp.

Plagányi, E.E., Rademeyer, R.A., Butterworth, D.S., Cunningham, C.L. and Johnson, S.J. (2007) Making management procedures operational - innovations implemented in South Africa. ICES Journal of Marine Science 64, 626632.

PMCC (2007) Consensus Statement on Management of Spatial Management of West Coast Fisheries. Pacific Marine Conservation Council, Astoria, OR, 6 pp.

Potvin, C. and Bernatchez, L. (2001) Lacustrine spatial distribution of landlocked Atlantic salmon populations assessed across generations by multilocus individual assignment and mixed-stock analyses. Molecular Ecology 10, 2375-2388.

Pritchard, J.K., Stephens, P. and Donnelly, P. (2000) Inference of population structure using multilocus genotype data. Genetics 155, 945-959.

Punt, A.E. (1992). Management Procedures for Cape Hake and Baleen Whale Resources. PhD thesis, University of Cape Town, 689 pp.

Punt, A.E. (2003) The performance of a size-structured stock assessment method in the face of spatial heterogeneity in growth. Fisheries Research 65, 391-409.

Punt, A.E. (2006a). Updated stock assessment of blue warehou (Seriollela brama) based on data up to 2006. Document presented to SlopeRAG, August 2006 (CSIRO Marine and Atmospheric Research).

Punt, A.E. (2006b) The FAO Precautionary Approach after almost 10 years: have we progressed towards implementing simulation-tested feedback-control management systems for fisheries management? Natural Resource Modeling 19, 441-464.

Punt, A.E. (2008) Refocussing stock assessment in support of policy evaluation. In: Fisheries for Global Welfare and Environment (Memorial Book of the Fifth World Fisheries Congress in Japan, October 2008) (eds K. Tsukamoto, T. Kawamura, T. Takeuchi, T.D. Beard Jr and M.J. Kaiser). Terra Scientific Publishing Company, Tokyo, pp. 139152.

Punt, A.E. and Donovan, G. (2007) Developing management procedures that are robust to uncertainty: lessons from the International Whaling Commission. ICES Journal of Marine Science 64, 603-612. 
Punt, A.E., Pribac, F., Walker, T.I., Taylor, B.L. and Prince, J.D. (2000) Stock assessment of school shark Galeorhinus galeus based on a spatially-explicit population dynamics model. Marine and Freshwater Research 51, 205-220.

Quinn, T.J. II and Deriso, R.B. (1999) Quantitative Fish Dynamics. Oxford University Press, New York.

Ralston, S. (2005) An Assessment of Starry Flounder off California, Oregon, and Washington. Pacific Fishery Management Council, Portland, OR, 86 pp.

Ralston, S. and Dick, E.J. (2003) The Status of Black Rockfish (Sebastes melanops) off Oregon and Northern California in 2003. Pacific Fishery Management Council, Portland, OR, 75 pp.

Rogers, J.B. (1994) Preliminary Status of the Splitnose Rockfish in 1994. Pacific Fishery Management Council, Portland, OR, $20 \mathrm{pp}$.

Ryder, O. (2003) Genetic studies in zoological parks and their application to conservation: past, present and future. International Zoo Yearbook 38, 102-111.

Sampson, D.B. (2005) The Status of Dover Sole off the U.S. West Coast in 2005. Pacific Fisheries Management Council, Portland, OR, 198 pp.

Sampson, D.B. (2007) The Status of Black Rockfish off Oregon and California in 2007. Pacific Fishery Management Council, Portland, OR, 236 pp.

Sampson, D.B. and Lee, Y.W. (1999) An Assessment of the Stocks of Petrale Sole off Washington, Oregon, and Northern California in 1998. Pacific Fishery Management Council, Portland, OR, $100 \mathrm{pp}$.

Sampson, D.B. and Wood, C. (2001) Stock Status of Dover Sole off the U.S. West Coast in 2000. Pacific Fishery Management Council, Portland, OR, 120 pp.

Schirripa, M.J. (2007) Status of the Sablefish Resource off the Continental U.S. Pacific Coast in 2007. Pacific Fishery Management Council, Portland, OR, 117 pp.

Schwartz, M.K. and McKelvey, K.S. (2008) Why sampling scheme matters: the effect of sampling scheme on landscape genetic results. Conservation Genetics (Online early, DOI: 10.1007/s10592-008-9622-1).

Schwartz, M.K., Tallmon, D.A. and Luikart, G. (1998) Review of DNA-based census and effective population size estimators. Animal Conservation 1, 293-299.

Schwartz, M.K., Luikart, G. and Waples, R.S. (2007) Genetic monitoring: a promising tool for conservation and management. Trends in Ecology and Evolution 22, 25-33.

Schwenke, P.L., Rhydderch, J.G., Ford, M.J., Marshall, A.R. and Park, L.K. (2006) Forensic identification of endangered Chinook Salmon (Onchorhynchus tshawytscha) using a multilocus SNP assay. Conservation Genetics $\mathbf{7}$, 983-989.

Seeb, L.W. and Gunderson, D.R. (1988) Genetic variation and population structure of Pacific ocean perch (Sebastes alutus). Canadian Journal of Fisheries and Aquatic Sciences 45, 78-88.
Seeb, L.W., Antonovich, A., Banks, M.A. et al. (2007) Development of a standardized DNA database for Chinook salmon. Fisheries 32, 540-552.

Selkoe, K.A., Henzler, C.M. and Gaines, S.D. (2008) Seascape genetics and the spatial ecology of marine populations. Fish and Fisheries (in press).

Sévigny, J.-M., Roques, S., Bernatchez, L. et al. (2003) Species identification and stock structure. In: Redfish Multidisciplinary Research Zonal Program (1995-1998): Final Report (ed. D. Gascon) Canadian Technical Report Fisheries and Aquatic Sciences 2462, xiii +139 pp.

Shaklee, J.B., Beacham, T.B., Seeb, L. et al. (1999) Managing fisheries using genetic data: case studies from four species of Pacific Salmon. Fishery Research 43, 45-78.

Siebenaller, J.F. (1978) Genetic variability in deep-sea fishes of the genus Sebastolobus (Scorpaenidae). In: Marine Organisms: Genetics, Ecology, and Evolution (eds B. Battaglia and J.A. Beardmore). Plenum Press, New York and London, pp. 95-122.

Skaug, H.J. (2001) Allele-sharing methods for estimation of population size. Biometrics 57, 750-756.

Smith, A.D.M. (1994) Management strategy evaluation: the light on the hill. In: Population Dynamics for Fisheries Management (ed. D.A. Hancock). Australian Society for Fish Biology, Perth, pp. 249-253.

Smith, P.J., Patchell, G. and Benson, P.G. (1981) Genetic tags in the New Zealand hoki Macruronus novaezelandiae. Animal Blood Groups and Biochemical Genetics 12, 37-45.

Smith, M.A., Woodley, N.E., Janzen, D.H., Hallwachs, W. and Hebert, P.D. (2006) DNA barcodes reveal cryptic host-specificity within the presumed polyphagous members of a genus of parasitoid flies (Diptera: Tachinidae). Proceedings of the National Academy of Sciences USA 103. 3657-3662.

Smith, A.D.M., Smith, D.C., Tuck, G.N. et al. (in press) Experience in implementing harvest strategies in Australia's south-eastern fisheries. Fisheries Research.

Smouse, P.E., Waples, R.S. and Tworek, J.A. (1990) A mixed fishery model for use with incomplete source population data. Canadian Journal of Fisheries and Aquatic Sciences 47, 620-634.

Stepien, C.A. (1995) Population genetic divergence and geographic patterns from DNA sequences: examples from marine and freshwater fishes. American Fisheries Society Symposium 17, 263-287.

Stepien, C.A. (1999) Phylogeographical structure of the Dover sole Microstomus pacificus: the larval retention hypothesis and genetic divergence along the deep continental slope of the northeastern Pacific Ocean. Molecular Ecology 8, 923-939.

Stepien, C.A., Dillon, A.K. and Patterson, A.K. (2000) Population genetics, phylogeography, and systematics of the thornyhead rockfishes (Sebastolobus) along the deep continental slopes of the North Pacific Ocean. Canadian Journal of Fisheries and Aquatic Sciences 57, 1701-1717. 
Stewart, I.J. (2005) Status of the U.S. English Sole Resource in 2005. Pacific Fishery Management Council, Portland, OR, $221 \mathrm{pp}$.

Stewart, I.J. (2007) Status of the U.S. Canary Rockfish Resources in 2007. Pacific Fishery Management Council, Portland, OR, $362 \mathrm{pp}$.

Swanson, P., Campbell, B., Shearer, K.D. et al. (2008) Application of reproductive technologies to captive breeding programs for conservation of imperiled stocks of Pacific salmon. Cybium 32, 279-282.

Sweijd, N.A., Bowie, R.C.K., Evans, B.S. and Lopata, A.L. (2000) Molecular genetics and the management and conservation of marine organisms. Hydrobiologia $\mathbf{4 2 0}$, 153-164.

Talman, S., Hamer, P., Robertson, S., Robinson, N., Skinner, A. and Smith, D.C. (2003) Stock structure and spatial dynamics of the warehou: a pilot study. Final Report of FRDC Project 2001/004. PIRVic, Marine and Freshwater Systems, Queenscliff, 72 pp.

Utter, F.M. and Hodgins, H.O. (1969) Lactate dehydrogenase isozymes of Pacific hake (Merluccius productus). Journal of Experimental Zoology 172, 59-67.

Utter, F.M. and Hodgins, H.O. (1971) Biochemical polymorphisms in the Pacific hake (Merluccius productus). Conseil international pour l'exploitation de la mer 161, 8789.

Utter, F.M., Teel, D.J., Milner, G.B. and McIsaac, D. (1987) Genetic estimates of stock compositions of 1983 chinook salmon, Oncorhynchus tshawytscha, harvests off the Washington coast and Columbia River. Fishery Bulletin (U.S.) 85, 13-23.

Villablanca, F. and Nakamura, R. (2007) Population Genetics of the Commercially Important Cabezon. Sea Grant R/MLPA05, Cal Poly San Luis Obispo, San Luis Obispo, 38 pp.

Vrooman, A.M. and Paloma, P.A. (1977) Dwarf hake off the coast of Baja California, Mexico. CalCOFI Report 19, $67-72$.

Wallace, J. and Lai, H.-L. (2005) Status of the Yellowtail Rockfish in 2004. Pacific Fishery Management Council, Portland, OR, 115 pp.

Wallace, F.R., Hoffmann, A. and Tagart, J.V. (1999) Status of the black rockfish resource in 1999. In: Appendix to the Status of the Pacific Coast Groundfish Fishery Through 1999 and Recommended Acceptable Biological Catches for 2000, Stock Assessment and Fishery Evaluation. Pacific Fishery Management Council, Portland, OR, 85 pp.

Wallace, F.R., Tsou, T.S., Jagielo, T. and Cheng, Y.W. (2006) Status of Yelloweye Rockfish (Sebastes ruberrimus) off the U.S. West Coast in 2006. Pacific Fishery Management Council, Portland, OR, 141 pp.

Wallace, F.R., Cheng, Y.W. and Tsou, T.S. (2007) Status of the Black Rockfish Resource North of Cape Falcon, Oregon to the U.S.-Canadian border in 2006. Pacific Fishery Management Council, Portland, OR, 120 pp.

Walters, C.J. and Martell, S.J.D. (2004) Fisheries Ecology and Management. Princeton University Press, Princeton, NJ.
Waples, R.S. (1991) Pacific salmon, Oncorhynchus spp., and the definition of "species" under the Endangered Species Act. Marine Fishery Review 53, 11-22.

Waples, R.S. (1998) Separating the wheat from the chaff: patterns of genetic differentiation in high gene flow species. Journal of Heredity 89, 438-450.

Waples, R.S. and Do, C. (2008) LDNE: a program for estimating effective population size from data on linkage disequilibrium. Molecular Ecology Resources 8, 753-756.

Waples, R.S. and Gaggiotti, O. (2006) What is a population? An empirical evaluation of some genetic methods for identifying the number of gene pools and their degree of connectivity. Molecular Ecology 15, 14191439.

Waples, R.S., Dickhoff, W.W., Hauser, L. and Ryman, N. (2008) Six decades of fishery genetics: taking stock. Fisheries 33, 76-79.

Ward, R.D. (2000) Genetics in fisheries management. Hydrobiologia 420, 191-201.

Ward, R.D. and Gardner, M.G. (1997) Stock Structure and Species Identification of School and Gummy Sharks in Australian Waters. Report of FRRF 93/11 \& FRDC 93/ 64. CSIRO Marine Research, Hobart.

Whitlock, M.C. and McCauley, D.E. (1999) Indirect measures of gene flow and migration: $F_{\mathrm{ST}} \neq 1 /(4 \mathrm{Nm}+1)$. Heredity, 82, 117-125.

Wishard, L.N., Utter, F.M. and Gunderson, D.R. (1980) Stock separation of five rockfish species using naturally occurring biochemical genetic markers. Marine Fishery Review 42, 64-73.

Withler, R.E., Beacham, T.D., Schulze, A.D., Richards, L.J. and Miller, K.M. (2001) Co-existing populations of Pacific Ocean perch, Sebastes alutus, in Queen Charlotte Sound, British Columbia. Marine Biology 139, 1-12.

Wright, S. (1931) Evolution in Mendelian populations. Genetics 16, 97-159.

\section{Appendix 1: Fred Utter's take on the genetic marker wars (unpublished data)}

\section{Hello SNPs}

With allozymes dying, fish workers were trying to replace now-defunct data bases that for decades had grown and become widely known as the key to identify places where fish populations from various nations and regions were all intermixing.

Allozymes got expensive as they got less extensive and support for them rapidly nixing.

Allozymes hit the basement. To find a replacement, new DNA tools claimed the day. 
Each crowing their merits, they were dangled like carrots,

asking management bodies to pay to develop, then sample - until data were ample to reach a new peak very fast for mixture solution with more resolution than allozymes did in the past.

Mitochondrial genomes were first seen as phenoms to reclaim salmon management's crown, but these female lines even failed to define what was known - this made managers frown.

Microsatellites came with immediate fame and abounding in loci, alleles.

Very soon major groups had the management troops strongly sniffing at microsat's heels.

Different groups had their foci on different loci. Different setups weren't very repeatable.
Analytical squeals from six dozen alleles suggested this tool was defeatable.

Among other blips, crept a tool known as SNPs with apparent explicit simplicity, proclaiming its wares based on nucleotide pairs, from proponents of zeal and felicity. This tool at this place is the primary basis of research intended to be a model - of course - for revealing the source of - sometime - every fish in the sea!!

Though it seems a bit chilling - living up to this billing

is our intention right from the get go.

So come one and all. We are having a ball. Your problems we pledge never to let go. 